\title{
¿CIUDAD O PUEBLO? IMAGINARIOS SOCIALES Y OTREDADES NÓMADES EN UNA CIUDAD MEDIA
}

\author{
Silvia Boggi ${ }^{1}$ \\ "Esa banda inconsolable de perros sin folleto, \\ brujas de alma sencilla, patéticos viajantes, \\ pobres tontos, pobres diablos, lunáticos diamantes \\ prometidos de carne, lánguidos, impalpables...". 2
}

En este trabajo nos proponemos brindar algunas líneas de abordaje interpretativo de los procesos de construcción y circulación de narrativas y sus prácticas asociadas que resultan de la construcción de otredades y fronteras morales en una ciudad bonaerense de rango intermedio. Tomamos como objeto de reflexión los imaginarios sociales locales referenciados en la llegada a la ciudad de Olavarría (provincia de Buenos Aires, Argentina) de simpatizantes de la banda de rock Los Fundamentalistas del Aire Acondicionado liderada por Carlos "Indio" Solari en marzo de 2017. Se trata de una banda de rock argentino identificada como una de las representantes del denominado "rock chabón", , de una amplia trayectoria musical que se plantea como continuidad (aunque con diferencias notables) respecto a la anterior banda -también liderada por Carlos Solari-llamada Patricio Rey y los Redonditos de Ricota. Entre otras características específicas, cabe señalar que desde hace décadas sus shows se realizan en espacios urbanos no metropolitanos e implican el desplazamiento e instalación ritual de miles de personas durante una temporalidad que excede la del recital en sí. Para tomar dimensión del fenómeno baste señalar que en el recital que la banda realizó en 2016 en la ciudad bonaerense de Tandil, el público asistente fue calculado en unas 200.000 personas, que equivalen - en términos generales- a casi el doble de la población estable de esa ciudad. ${ }^{4}$

\footnotetext{
${ }^{1}$ Universidad Nacional del Centro de la Provincia de Buenos Aires, Argentina.

2 De "Buenas noticias", álbum "Lobo suelto, cordero atado", Vol. I de Patricio Rey y los Redonditos de Ricota.

${ }^{3}$ Bajo esa denominación se identifica a un cierto tipo de rock nacido en Argentina en la década de los '90, con fuertes marcas de clase, barriales y futboleras, modelado en sensibilidades contextualizadas en tiempos de aplicación del neoliberalismo y sus consecuencias sociales. Se trata de un complejísimo fenómeno de producción y fundamentalmente de escucha resignificada, con una particular estética y modos de reproducción, como de relación entre público y bandas musicales. "Chabón, es un argentinismo que, en el lenguaje coloquial, significa muchacho, chaval o pibe, asociando el término a algo que va más allá de la edad o la juventud y aludiendo al origen en el barrio o el arrabal”. (Semán, 2005: 241).

4 Información en nota periodística http://www.lacapitalmdp.com/cerca-de-200-mil-personas-vibraroncon-el-recital-del-indio-solari-en-tandil/
} 
Nuestra reflexión se orienta, por un lado, hacia la articulación entre narrativas actuales respecto de la llegada de la banda a la ciudad de Olavarría en 2017 y el entramado significacional que forma parte del suelo histórico de la relación entre los fans de "los Redondos", su líder, la banda y esta ciudad, en donde su actuación fuera prohibida hace 20 años. Por otro, interesa atender al juego de contradicciones e interpelaciones a los prejuicios, estereotipos y formas discriminatorias que atraviesan los imaginarios sociales ${ }^{6}$ de sentido común dominante local respecto del nomadismo ocasional que implica la llegada de seguidorxs de la banda, que forman parte del entramado que teje el dilema olavarriense encabalgado en la tensionada definición de ser ciudad o pueblo.

Más allá de las clasificaciones conceptuales respecto de los imaginarios sociales urbanos en cuanto a su fuente de emisión ${ }^{7}$, nuestro análisis se nutre de la circulación y articulación de todos ellos constituyendo un corpus que aparece plasmado en notas en prensa gráfica local y regional (actuales y de 1997), posteos en Facebook y mensajes de Whatsapp aparecidos en los días que antecedieron a la realización del recital. Asimismo registramos discursos y prácticas de distintos actores sociales locales que, por fuera del espacio mediático y de redes sociales pero estrechamente relacionados- formaron parte de la corriente enunciativa que es motivo de nuestra indagación. Como sostiene Ana Silva (2015: 60).

\footnotetext{
5 "Redonditos", "los Redondos", "los Redó" son expresiones lingüísticas simplificadas para referir al nombre completo de la banda: Patricio Rey y los Redonditos de Ricota. La expresión "El Indio" tiene la capacidad de condensar el nombre completo del artista (cantante de la banda) y a la banda misma. El término "ricotero/a" alude a seguidorxs, fans del grupo musical.

6 "El imaginario urbano incluye las imágenes y representaciones referenciadas en el espacio de la ciudad, tal como lo define Armando Silva: "uso e interiorización de los espacios y sus respectivas vivencias dentro de la intercomunicación social" (1992: 15), y sus relaciones con las prácticas, valores y predisposiciones de habitus (como lo enunciara Pierre Bourdieu, 1990) que conformarían la cultura (en un sentido antropológico) urbana y sus distintas formas de adquirir identidad. El espacio, en consecuencia, es concebido no como mero ente físico sino como un espacio vivido por los actores" (Gravano, 2005: 12)

7 "Dentro de la sistematización de nuestro objeto, hemos establecido una clasificación del imaginario, de acuerdo con sus fuentes. Por un lado está el imaginario institucional, cuya fuente de emisión y producción puede detectarse en los documentos, prácticas y discursos oficiales (estado, gobierno, instituciones, textos escolares, etc.). También está el imaginario erudito, compuesto por el conjunto de imágenes de la ciudad presentes (en forma explícita o subyacente) en los estudios académicos, principalmente en las historias locales de las ciudades. Por otra parte, está el imaginario de sentido común, que es el que se construye en forma colectiva, que puede coincidir o no con el oficial (si éste es hegemónico), que puede ser calificado de popular -en un sentido gramsciano-, en la medida que se oponga al hegemónico, y que es el que inicialmente fue objeto de nuestros trabajos. Y finalmente el imaginario massmediático, cuya fuente de emisión son los medios de difusión." (Gravano, 2005: 13). En trabajos posteriores (Boggi, 2011: 309) incluimos los ciberimaginarios sociales como otra modalidad de expresión de los imaginarios sociales en instancias de mediación tecnológica y en el ciberespacio.
} 
Se trata de procesos que no siempre pueden ser observados de manera presencial y directa, ya que se fundan en modos de interacción multisituados, cuyo alcance sólo puede ser abordado de manera limitada y fragmentaria. Pero, pese a su aparente virtualidad, como ha señalado Estela Grassi (2004), no hay que perder de vista que se trata de dimensiones bien concretas de la vida social, en las que circulan, se producen, reproducen y cuestionan las categorías que clasifican a los grupos sociales, así como los recursos de percepción e interpretación de la realidad social.

Planteamos al mismo tiempo la indisociabilidad entre las llamadas "misas ricoteras" ${ }^{\prime 8}$ y las ciudades de rango intermedio ${ }^{9}$, atendiendo al hecho de que se trata de un complejo fenómeno social itinerante que - remarcamos - en las últimas décadas asume un carácter no metropolitano ${ }^{10}$. En este sentido es que nuestro acercamiento cobra interés pretendiendo poner sobre el tapete ciertas especificidades de las ciudades intermedias frente al hecho concreto de la ocupación territorial urbana por parte de multitudes durante varios días, modificando las cotidianeidades ligadas a los usos y disfrute de la ciudad y la ciudad misma como acontecimiento vivido.

Podemos situar el inicio de nuestros registros a partir de las primeras especulaciones que en los últimos meses de 2016 eran sostenidas-tanto en los medios de comunicación locales, regionales y nacionales, páginas de internet, redes sociales, como por parte de lxs seguidorxs del Indio Solari y su banda actual-en relación con el lugar en donde se realizaría el próximo concierto. Esta situación se agudizó especialmente cuando se tuvo la certeza de que por decisión de las nuevas autoridades del Hipódromo de Tandil - donde se llevaron a cabo algunos de estos espectáculos - esa ciudad bonaerense ya no volvería a ser sede de los conciertos de la banda.

\footnotetext{
${ }^{8}$ Término de uso generalizado en el sentido común que refiere al aspecto ritual y con atribuciones de cierta sacralidad del recital y el entorno espacio-temporal previo al mismo. El adjetivo se vincula con el nombre de la banda anterior a la actual, liderada por el "Indio" Solari: Patricio Rey y los Redonditos de Ricota. Los y las fans del grupo de rock se autodenominan "ricoterxs".

${ }^{9}$ La categoría de ciudad media o intermedia suele construirse a partir de indicadores estructurales y de funcionalidad, en un rango poblacional amplio que abarca desde los 50.000 a los 500.000 habitantes. En nuestros propios desarrollos analíticos intentando aportar al conocimiento de la especificidad de las ciudades de rango intermedio sostenemos la necesidad de considerar previamente el contexto sociohistórico, el aspecto relacional que implica la definición y el entramado significacional que asume el espacio urbano. Cfr. Boggi y Galván (2016); Gravano (2005).

${ }^{10}$ Según refieren crónicas de la banda, "En 1995 comienza la marcha de las bandas ricoteras por el país. Además de Mar del Plata, Rosario y Santa Fe copan Tandil, Villa María y San Carlos, un pueblo de Santa Fe con población de diez mil visitada por otros diez mil fans redondos. En diciembre de 1996, Pedro Spina, intendente de Arroyo Seco (Santa Fe) negó autorización para los shows. En agosto del 97 Helios Eseverri, su par de Olavarría, prohibió su actuación por "los reiterados episodios de violencia y desorden": había 12 mil entradas vendidas". Archivo Sí.com.

Desde 2005 a 2016, la banda ha brindado recitales en La Plata, Jesús María, Tandil, San Luis, Salta, Junín, Mendoza, Gualeguaychú (en Argentina) y en Montevideo (Uruguay).
} 
En uno de los medios gráficos tandilenses, la nueva gerencia del Hipódromo de Tandil, dependiente de Loterías de la Provincia de Buenos Aires, en la voz de su Administrador, declaró, adhiriendo a la corriente significacional hegemónica respecto de la banda: "No queremos volver al club que tuvo el Indio, que nos destrozaron la institución. Eso es algo que no va a volver a pasar nunca más". Añadió que "la orden de Loterías es nunca más destrozar una obra que cuesta tanto dinero y tiempo". Reconoció que los masivos shows de Solari en Tandil,

son necesarios para la ciudad, que sale reconfortada con el Indio, pero no es el lugar adecuado. 150 mil personas son indominables. Tenemos pistas nuevas, empalizadas nuevas, parques nuevos, porque se está parquizando todo. ¿Cómo hacemos para manejar ese malón de gente?, insistió en las declaraciones televisivas. Si bien admitió que "el espacio físico de la parte central existe, ahora no va a estar preparado para un recital". 11

A partir de allí sectores dirigenciales de algunos centros urbanos comenzaron a ofrecer instalaciones y la infraestructura necesaria para la realización del multitudinario recital en sus localidades y a intentar gestionarlo con representantes de la productora del show. Se trató de ciudades bonaerenses de rango intermedio que emprendieron la disputa para lograr convertirse en espacios de despliegue de la llamada "misa ricotera": Pehuajó, Junín (con la experiencia del concierto del Indio en 2011), Moreno, Azul y Olavarría, que finalmente resultó ser la elegida.

En estas pujas los sectores dirigenciales de cada centro urbano postulante enunciaron sus potencialidades para la realización del evento condensadas en dos variables: ubicación geográfica considerada estratégica y posesión de espacios calificados como acordes a la dimensión y desarrollo del recital. En el perfil de Facebook del Intendente de Pehuajó ${ }^{12}$ puede leerse:

ofrecemos la infraestructura necesaria para que pueda presentarse en nuestra ciudad. Somos muy respetuosos de la cultura popular que representa el "indio" Solari y en consonancia con lo que venimos haciendo en 9 años de gestión de apoyar las expresiones en todos los géneros del arte, ofrecemos Pehuajó para que pueda realizar aquí su presentación. He mantenido contacto con terceras personas como vía de comunicación allegadas al artista, para manifestar que Pehuajó dispone los espacios para albergar un evento masivo como lo es cada presentación, que en la última edición en Tandil convocó alrededor de 200.000 personas, uno de los hechos sociales, culturales y económicos más significativos para la ciudad y la región.

\footnotetext{
${ }^{11}$ ABChoy, del 28-10-2016 (el señalado en itálica es nuestro).

${ }^{12}$ https://www.facebook.com/PabloJavierZurro/photos/a.589935711061235.1073741827.1162637350951

04/1137754999612634/?type=3\&theater
} 
Queremos al Indio Solari en Pehuajó y estamos a disposición para que concretar su espectáculo aquí. Reunimos las condiciones para montar un evento masivo así como la decisión firme de apoyar la concreción de esta posibilidad.

Desde Junín, un medio gráfico on line expresaba

Ahora la posibilidad de que la ciudad sea nuevamente el escenario de una "misa" india está latente. Junín tiene ciertas características que la vuelven "única" a la hora de evaluar su condición para albergar a otra ciudad (hasta de más habitantes) durante algunos días. Está sobre dos rutas nacionales importantes: la 7 y la 188 . Se encuentra, dentro de la Provincia, en un lugar estratégico: está relativamente cerca de las principales ciudades del país: 200 kms de Rosario; 260 de Buenos Aires y un poco más de 600 de Córdoba. Además es la referencia en cuanto a salud de la región y ya demostró que puede soportar a la congregación ricotera.

La comuna de Moreno ofrecía

las instalaciones del Dique Roggero para que [el "Indio" Solari] realice su presentación. El lugar ofertado es un inmenso espacio verde, con una represa y un área protegida. Es un lugar de esparcimiento muy conocido y utilizado por la gente de Moreno y también por los vecinos de los municipios vecinos.

En el caso de Azul, los funcionarios expresaron que la ciudad "tiene una ubicación geográfica estratégica por su cercanía con Olavarría y Tandil, y precisaron que "cuenta con dos o tres espacios al aire libre en los que tranquilamente puede realizarse el recital".

Escuetas fueron las menciones respecto de la dimensión económica del fenómeno -seguramente evaluada en ruedas comunicacionales de acceso restringido- y tampoco se evaluó por estos medios la existencia de posibles cuestionamientos por parte de la ciudadanía, no convidada a la hora de tomar este tipo de decisiones. El haz de generosos ofrecimientos aparecía mediáticamente ligado a una serie de vínculos político partidarios y de cercanía con representantes del artista y su banda que irían a decantar en la elección de la ciudad como una presea, como un premio derivado de "oportunas negociaciones y gestiones" adjudicadas a las autoridades municipales locales.

El 21 de noviembre de 2016, el Intendente de la ciudad, Ezequiel Galli, anunciaba en su cuenta de Twitter: El \#Indio viene a dar misa a Olavarria. Poco después de que se confirmara que el recital de rock con mayor convocatoria del país se realizaría en el predio La Colmena de la ciudad de Olavarría en marzo de 2017, la ciudad se sobrepuso a la inicial sorpresa. La euforia, algo de revancha ${ }^{13}$ y el anticipado cálculo de

${ }^{13}$ La prohibición de la banda por medio de un decreto municipal en 1997 fue un hecho que tomó repercusión mediática nacional y colocó a la ciudad, su gente y su intendente de entonces en el centro de innumerables debates, con un saldo no demasiado positivo para sus imágenes. 
réditos de algunos, la inquietud y el incipiente y sostenido disgusto y temor de otrxs, hicieron temblar su historia y las réplicas, atravesando la densidad temporal, pusieron pie en el presente. Amasando sobre antiguas mesas las harinas de costales nuevos y levando sobre mesas nuevas las viejas harinas del pasado, se fueron alimentando representaciones y prácticas acerca de quienes irían llegando, de todxs los modos posibles y a toda hora, desde una semana antes del recital. Esxs nómades insistentes -

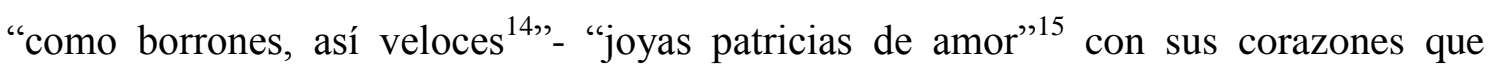
guardan nombres banderamente rojos, negros y de lienzo blanco, "los chicos, las pibitas de barrios desangelados" $" 16$...

Veinte años después de la prohibición de sus recitales decretada por el Intendente de entonces, Helios Eseverri y su arco de solidaridades local, la errancia musical ricotera hacía realidad el grafiti que en 1997 apareció, pintado en rojo en las paredes del Palacio Belgrano, con la $\mathrm{P}$ coronada $^{17}$, leída en ese entonces como signo vandálico: Volveremos.

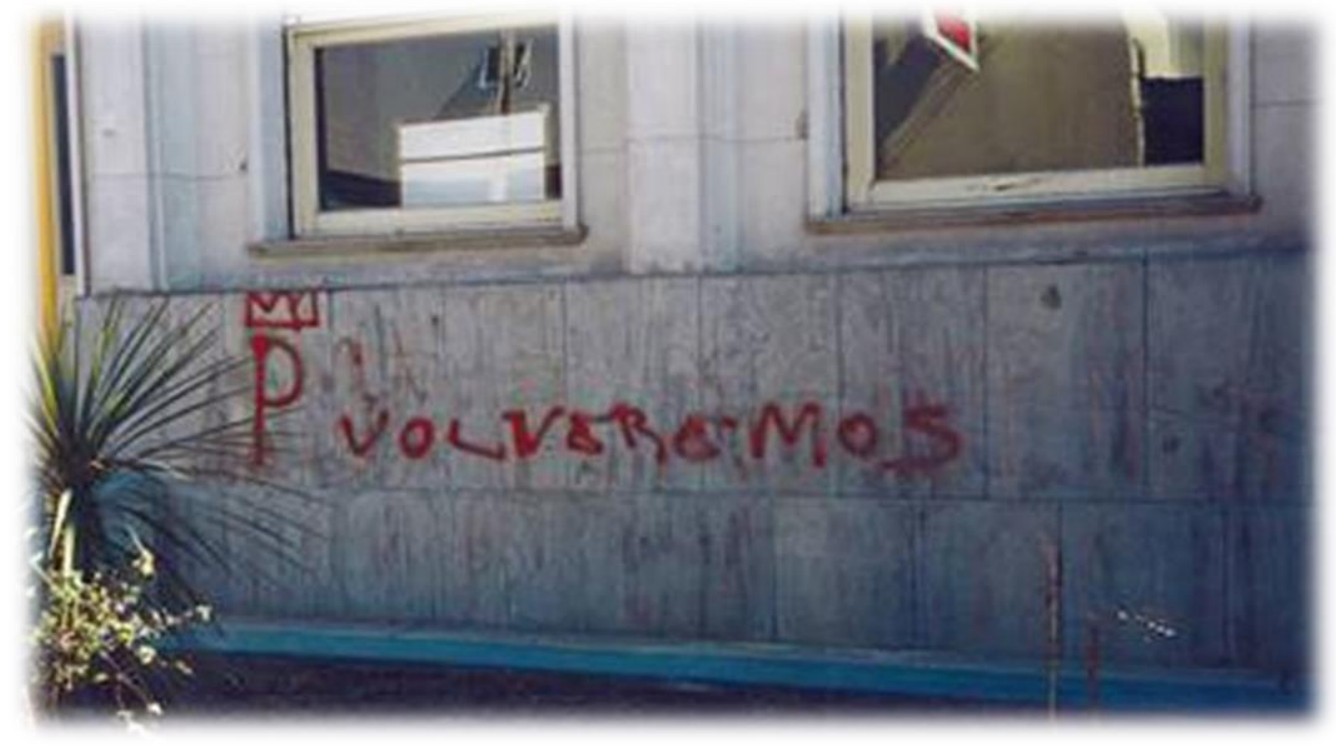

Foto 1: Informe de la DIPPBA

(Dirección de Inteligencia de la Policía de la Prov.de Buenos Aires), 1997.

\footnotetext{
${ }^{14}$ Referencia al tema Juguetes Perdidos, de la banda Patricio Rey y sus Redonditos de Ricota, compuesta por Skay Beilinson y el Indio Solari, incluida en el álbum Luzbelito, de 1996.

${ }^{15}$ Referencia al tema Música para pastillas, de la banda Patricio Rey y sus Redonditos de Ricota, incluida en el álbum Oktubre, de 1986.

${ }^{16}$ En una entrevista al diario Clarín el 25 de junio de 1999, Solari definió a quienes asisten a sus recitales como "chicos de barrios desangelados, que no saben de discotecas para modelos y estrellas de rock, ni de autos locos ni de navidades artificiales. Pibitas embarazadas que lloran su dolor en una esquina... chicos bombardeados, sin padres ni hermanos, con la esperanza arrodillada a los pies de la recaudación de un taxi."

${ }^{17} \mathrm{La}$ P coronada es el símbolo de la banda Patricio Rey y los Redonditos de Ricota.
} 


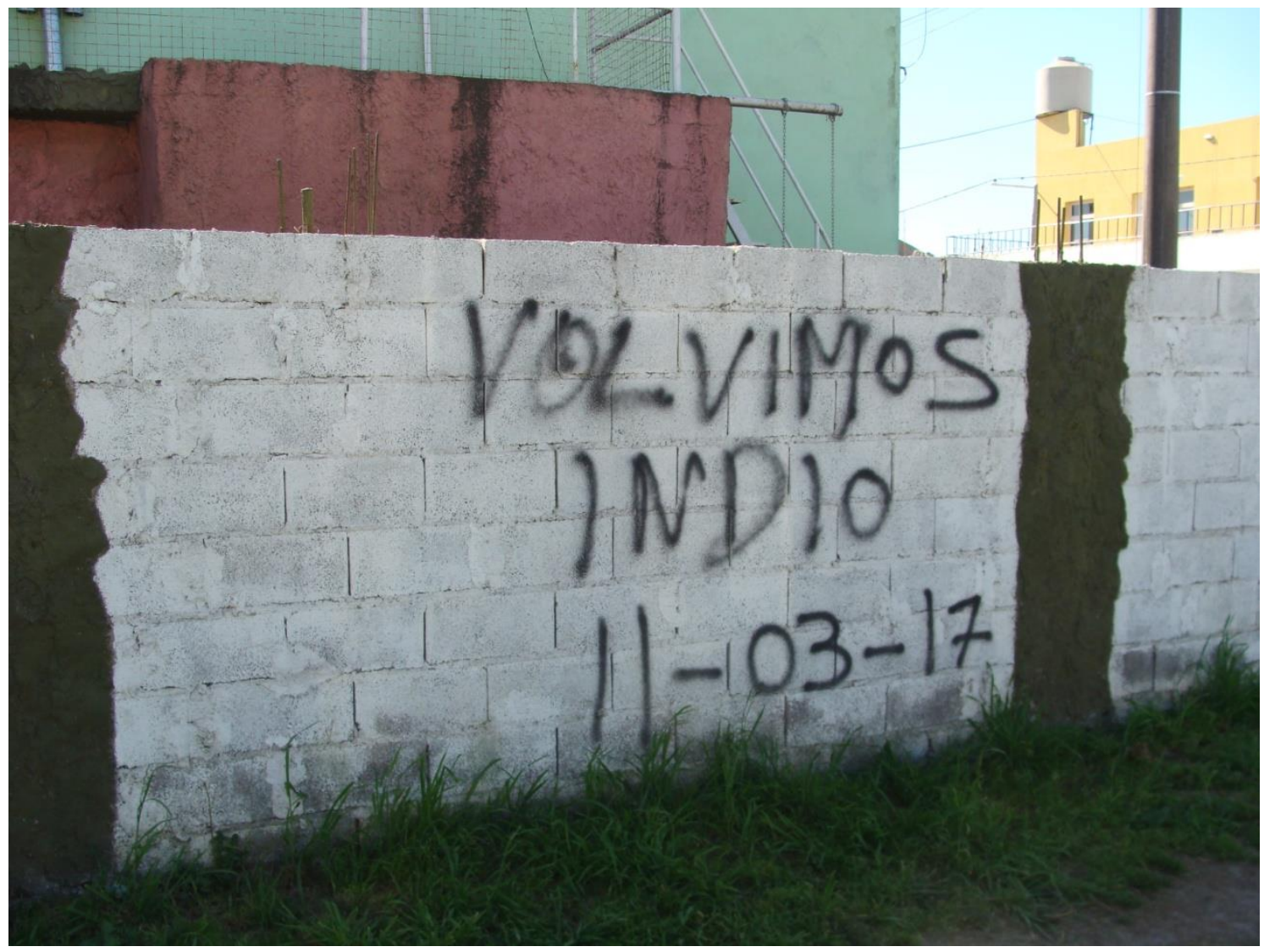

Foto 2: Silvia Boggi, marzo 2017.

\section{El Perfume de la tempestad y Todos a los botes ${ }^{18}$ : rapto etnográfico de "la previa"}

Miércoles 8 de marzo de 2017, 18:15 hs.

A tres días del recital. Camino hacia la plaza central para participar de la marcha convocada por el día de la mujer, cae el sol y las calles se van poniendo azules. Me acabo de bajar de un remis en donde la temática de charla desde que salimos de mi casa es el recital del Indio y de cómo la ciudad va a hacer para recibir "a todos esos"... "son bravos los ricoteros" (me espía el remisero de unos cincuenta y pico por el espejo retrovisor buscando complicidad). Le parece? Concedo. "See, ya andan dando vueltas por todos lados, han afanado algunos negocios... y de paso los chorros de acá aprovechan la volada y afanan también... y hoy yo es el último día que trabajo... ya le dije a mi mujer: me voy. Me voy a pescar y vuelvo cuando todo esto haya pasado. Si ella quiere venir, que venga. Me perderé unos días de trabajo pero los voy a ganar en

\footnotetext{
${ }^{18}$ Referencia a dos títulos de temas de la banda Indio y los Fundamentalistas del Aire Acondicionado, El perfume de la tempestad y Todos a los botes, pertenecientes al álbum El perfume de la tempestad, 2010.
} 
tranquilidá. Usté sabe lo que va'ser esto el sábado? Un desastre, no se va a poder andar..."

Las calles del centro no tienen una apariencia diferente a la de "todos los días". Algunas parejitas jóvenes, grupos de dos o tres pibes que caminan, jeans, zapatillas, remeras negras y otras de colores con inscripciones reveladoras de su adscripción ricotera: Indio (se lee en la espalda) y el lugar y fecha de algún recital. Al frente, la fantástica imagen que Rocambole creó para Oktubre y la leyenda Patricio Rey y los Redonditos de Ricota. "Nadie es capaz de matarte en mi alma", "Fue mi único héroe en este lío", "El amor empezó a quedarte chico", fragmentos de letras de las canciones rescatadas como afirmaciones categóricas para la vida, paseadas y ostentadas en remeras. Sólo eso. En el centro de la ciudad todavía no se canta ni se pernocta ni se comparte grupal y ritualmente.

A la vuelta de la marcha me detengo para mirar una vidriera, en la esquina de Necochea y Rivadavia y estoy en eso cuando dobla una mujer de unos cuarenta años, robusta y rubia, los ojos claros y la cara enrojecida, agitada como quien viene de correr. "Reventaron La París!!”, grita desesperada y me sobresalto. "Reventaron la París!! Cierren, cierren ya mismo!!! Dicen que están viniendo para acá!!” gesticula.

“¿Cómo?” (dicen los dueños del negocio que estaban charlando amablemente en la vereda). "Sí -explica la mujer, con una veloz verborragia- entraron unos ricoteros a pedir sánguches y como no les dieron, salieron y rompieron todos los vidrios!! Recién me avisaron, acá a la vuelta, cierren, cierren si no se quieren quedar sin nada!!”, casi jadea. El negocio sigue abierto a pesar de la noticia...

Apenas unos minutos después y de regreso a casa, paso frente a La París. La tradicional confitería frente a la plaza central de la ciudad luce impecable, sus consuetudinarios parroquianos cumplen con el hábito del café de la tarde. Nada de vidrios quebrados, nada que denote algún acto de violencia. Facebook está a full con la misma narrativa: tanto se repite que los dueños de La París se ven obligados a desmentir enfáticamente que haya sucedido algún incidente y lo publican en las redes sociales ${ }^{19}$. Así y todo hay quien insiste - enredada en el fantasma urbano -: "yo vi cuando

\footnotetext{
19 En Facebook [Estado], 9 de marzo de 2017. https://www.facebook.com/La-Paris-Resto-Caf\%C3\%A9989088747837137/?ref=br_rs. Texto del posteo: "Hola. Queríamos desmentir una versión que anda dando vueltas sobre un grupo de seguidores del indio que se habrían sentado a comer y levantado sin pagar. No sabemos de dónde surgió el rumor pero es mentira, no hemos tenido por el momento ningún tipo de problema con los fanáticos. Gracias!"
} 
cambiaban el vidrio". Algunos le responden el posteo subiendo la declaración de los dueños de "La París" y le sugieren que vaya al oculista o "cambiá los lentes, che..."

"En Filippo sí se fueron sin pagar" ${ }^{20}$ comenta otra vecina tenaz en fogonear rumores desacreditadores; la dueña del negocio aclara que "sí...pero no sé si no son de acá" y otra agrega a la cadena de posteos: "Por favor paren con la sicosis...la gente actúa como si viniera una guerra. Qué circo...bien por la actitud de la paris". ${ }^{21}$

Otros, indignados frente a la constatación de que "mearon y cagaron en el césped de mis canteros", rememoran la carta que los vecinos de los barrios San Vicente Sur y Los Robles habían enviado al intendente en la que expresaban su intranquilidad, su preocupación y su estado de temor por "la venida de más de 200.000 personas (el doble de habitantes de la ciudad) para el recital del Indio Solari”. En ella se preguntaban entre otras cuestiones - por la cantidad de desechos orgánicos de tantxs asistentes deambulando e instalados precariamente en la zona, si no se aseguraba la infraestructura necesaria... "Se hizo una anarquía y se sabía. Están haciendo sus necesidades y haciendo fuego ${ }^{22}$ en veredas y rotondas. Feliz ciudad sitiada"23 escribió en Facebook una vecina olavarriense.

${ }^{20}$ En Facebook, 9 de marzo de 2017. https://www.facebook.com/La-Paris-Resto-Caf\%C3\%A9989088747837137/?ref=br_rs.

${ }^{21}$ En Facebook [comentario] Comunicación de SL, 9 de marzo de 2017. https://www.facebook.com/LaParis-Resto-Caf\%C3\%A9-989088747837137/?ref=br_rs. Mantuvimos la grafía.

${ }^{22}$ Se trata del armado y encendido de pequeños fogones para asar, cocinar, calentar agua y acercar calor a las personas que se reúnen a su alrededor para mitigar los rigores del clima otoñal en la zona de realización del recital.

${ }^{23}$ En Facebook [comentario], publicación de FG, 8 de marzo de 2017. 


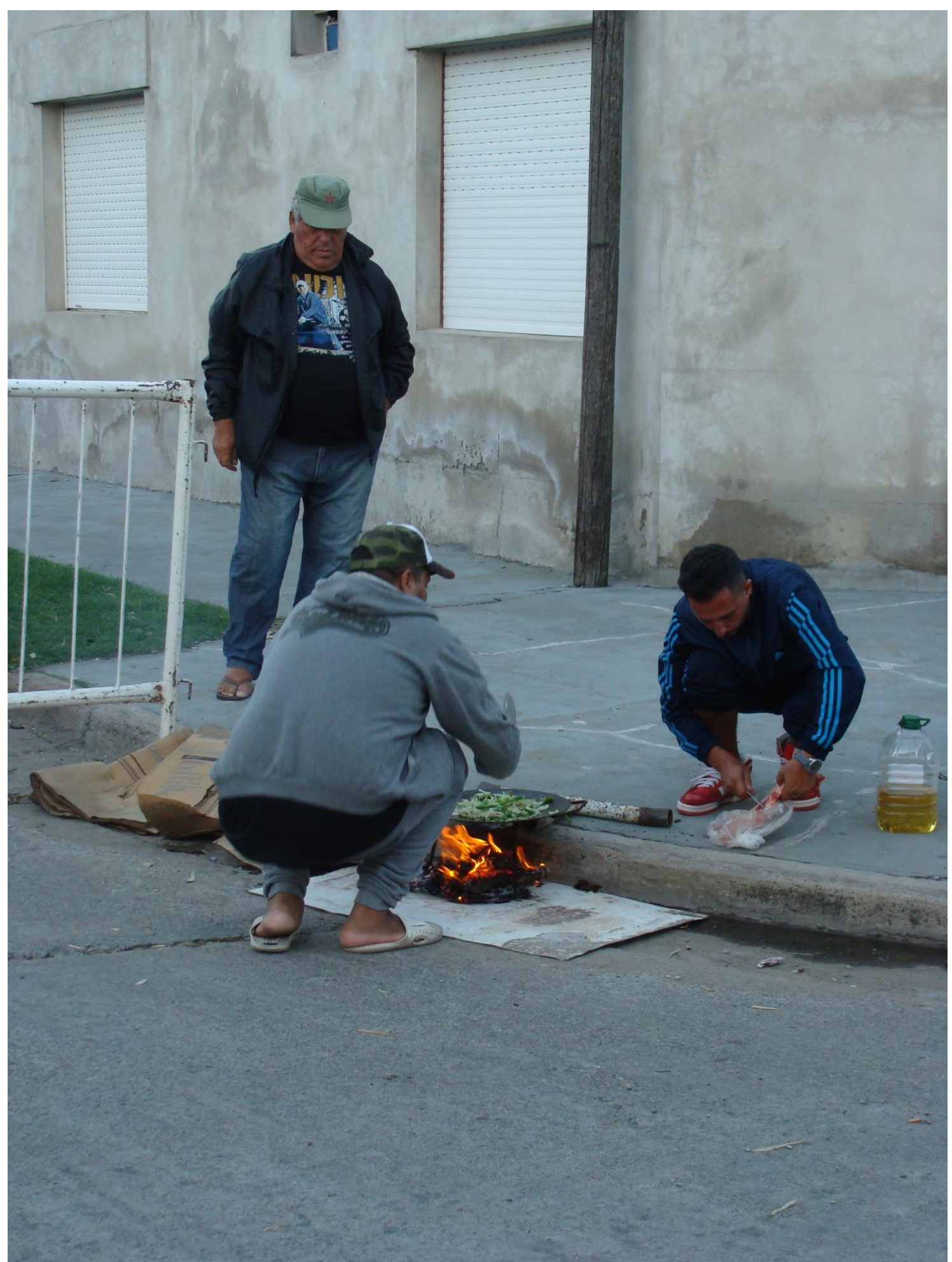

Foto: Silvia Boggi, 9 de marzo 2017. 
A medida que pasan las horas, la red social Facebook funciona como una caja de resonancia de lo que supuestamente está experimentando la vecindad local. Es generosa en posteos encendidos y atizadores de todos los temores: ricoteros llegados a la ciudad que cometen asaltos en los semáforos, negocios que anuncian que van a cerrar sus puertas desde el viernes, fotos de la avenida Avellaneda (el epicentro del recital) con los primeros kioscos y "acampes" en las veredas, en terrenos baldíos o en patios convertidos repentinamente en campings por unos precios nada módicos. Como un revuelo de pájaros asustados se agita lo cotidiano, "soplando brasas"24 en semiadormecidos prejuicios, desperezando el miedo.

"Lo que hice fue cerrar mi casa. Por estos días. No abro ventanas, salimos y cerramos la puerta con llave por prevención, viste (dice Gabriel, con gesto condescendiente, un ingeniero olavarriense de 63 años). Toda mi familia está encerrada, los chicos no salen. Me dio curiosidad y fui a la calle Avellaneda, me puse la campera más vieja y rota que tenía y fui”. Por qué fuiste con esa campera? pregunto desafiándole el prejuicio. "Por si me robaban...por las dudas, no fuera a ser que...estos no son cualquier nene...je"

Mientras tanto, los vecinos del coqueto y residencial barrio que se levanta a la vera de la Avellaneda (muchos de ellos reconocidos profesionales) han invertido algo de su capital en cerveza e intentan vender la bebida a precios exorbitantes. La misma situación se presenta con las comidas al paso, la carga de baterías de celular, el uso de los baños privados ante la ausencia de baños químicos públicos. "Pero resulta que los ladrones son 1xs visitantes", ironizan posteos en Facebook, denunciando el abuso: "Ahora entiendo lo de la horda!!! Cobran 50 pe una carga de tel, 80 pe una birra, 60 pe un chori!!! Ahora entiendo!!!!!!”, “no sean lacras, no le roben así a los pibes!!!! ${ }^{25}$

Hubo quien ahuyentando los espectros discursivos $-\mathrm{y}$ seguramente sin haber asistido jamás a un recital del Indio- compró un espacio dentro del predio donde se llevaría a cabo el espectáculo, 30.000 chorizos y 20.000 latas de cerveza, pensando "hacer una diferencia" con el kiosquito efímero. Y otros tantos remedaron la práctica:

\footnotetext{
${ }^{24}$ Referencia a la letra del tema Juguetes Perdidos compuesto por Skay Beilinson y el Indio Solari de la banda Patricio Rey y sus Redonditos de Ricota, incluido en el álbum Luzbelito, de 1996.

${ }^{25}$ En Facebook [comentario] MDB, una vecina olavarriense, (comunicación personal del 8 de marzo de 2017). "Pe" funciona en el lenguaje coloquial como una abreviatura de la palabra pesos, "tel" refiere al teléfono celular, "birra" equivale a cerveza (en este caso la envasada en lata) y "chori" es la abreviatura de choripán, un alimento del repertorio culinario popular de Argentina.
} 
vendieron autos o solicitaron créditos bancarios para comprar mercadería para vender especialmente- durante "la previa" ${ }^{26 "}$.

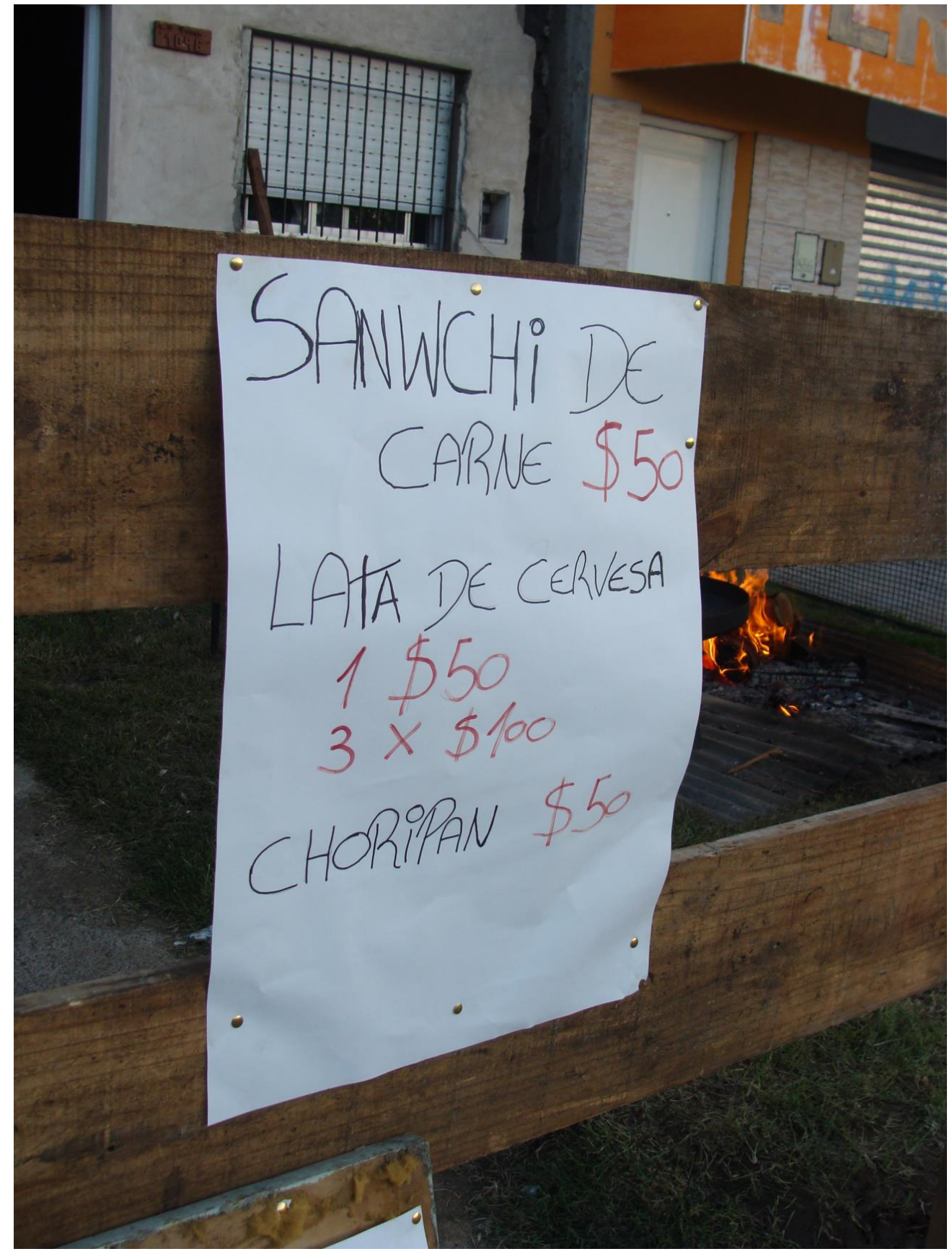

Foto: Silvia Boggi, 09 de marzo 2017.

\begin{abstract}
${ }^{26}$ Desde los imaginarios sociales expresados en discursos de asistentes a recitales, la "previa" puede interpretarse como el tiempo-terrritorio (un cronotopo) anterior a la realización del recital, donde se comparte ritualmente el espacio y lo que se consume, se celebra el reencuentro amistoso y solidario entre quienes son seguidorxs de la banda y se confraterniza con otrxs. Puede tratarse de días o de horas y se realiza en los alrededores del espacio donde tendrá lugar el espectáculo. Dada la masividad de los eventos culmina realizándose en cualquier espacio de la ciudad, sin importar la distancia al lugar donde está ubicado el escenario.
\end{abstract}


Es que ni bien se supo que Olavarría sería la sede de la "misa ricotera",27, las distribuidoras mayoristas de alimentos y bebidas existentes en la localidad también especularon con obtener ingentes ganancias y promocionaron sus artículos mediante folletos que expresaban: "tenemos todo para el recital Indio", que eran repartidos por la ciudad, incitando a ser parte de la "movida económica" que se le atribuye a la realización de este tipo de espectáculos masivos.

Los medios gráficos de la zona ${ }^{28}$ anunciaron creaciones culinarias en panaderías locales: una variedad de masas a las que apodaron "redonditos de ricota", como homenaje y como estrategia comercial. Aparecieron también quienes amasaron panes de manera artesanal en sus casas y terminaron regalándolos entre ruedas de rock de "la previa”, en plena calle, o quienes brindaron agua caliente para el mate, permitieron "pasar al baño" o cargar celulares, instalar carpas o inventar toldos en patios y jardines y hasta compartir habitaciones, muebles e instalaciones de sus propias casas sin cobrar un centavo.

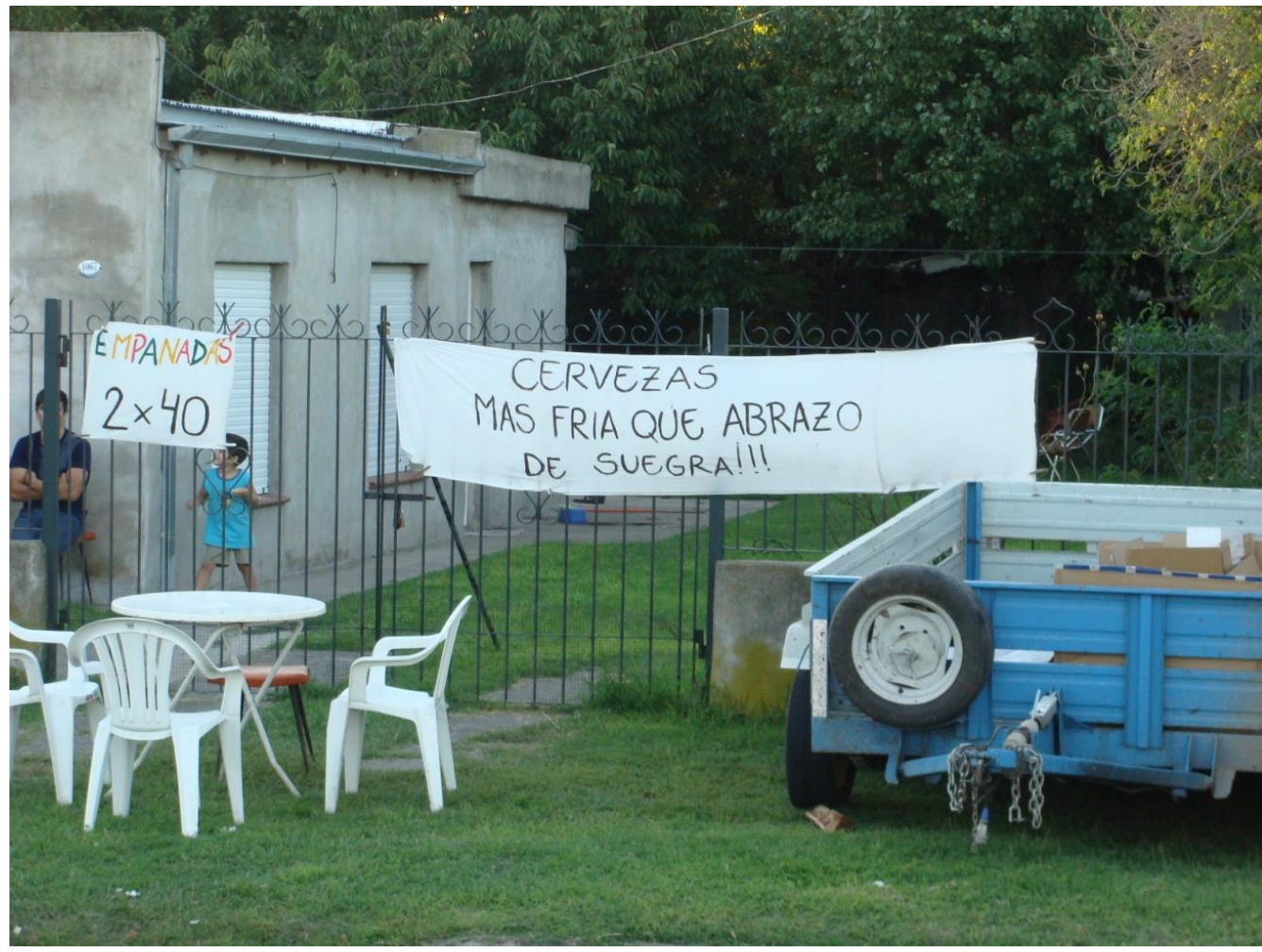

Foto: Silvia Boggi, 9 de marzo 2017.

\footnotetext{
${ }^{27}$ Con esa denominación se alude desde el sentido común al acontecimiento de la realización de cada recital y el desplazamiento de sus seguidorxs y sus implicancias simbólicas.

${ }^{28} \mathrm{https}$ ://www.diarioeltiempo.com.ar/la-misa-ricotera-ya-se-palpita-en-olavarria.html
} 
Algunos olavarrienses alambraron terrenos baldíos de ignotos propietarios ausentistas con la intención de improvisar un cámping y otros alquilaron sus veredas a altísimos precios, porque a menos de 48 horas de conocida la noticia, la ciudad se quedó sin plazas hoteleras libres para esos días. Lo mismo ocurrió con los hoteles de ciudades vecinas. Muchos patios olavarrienses - alquilados o no- cumplieron la función de recibir a lxs visitantes.

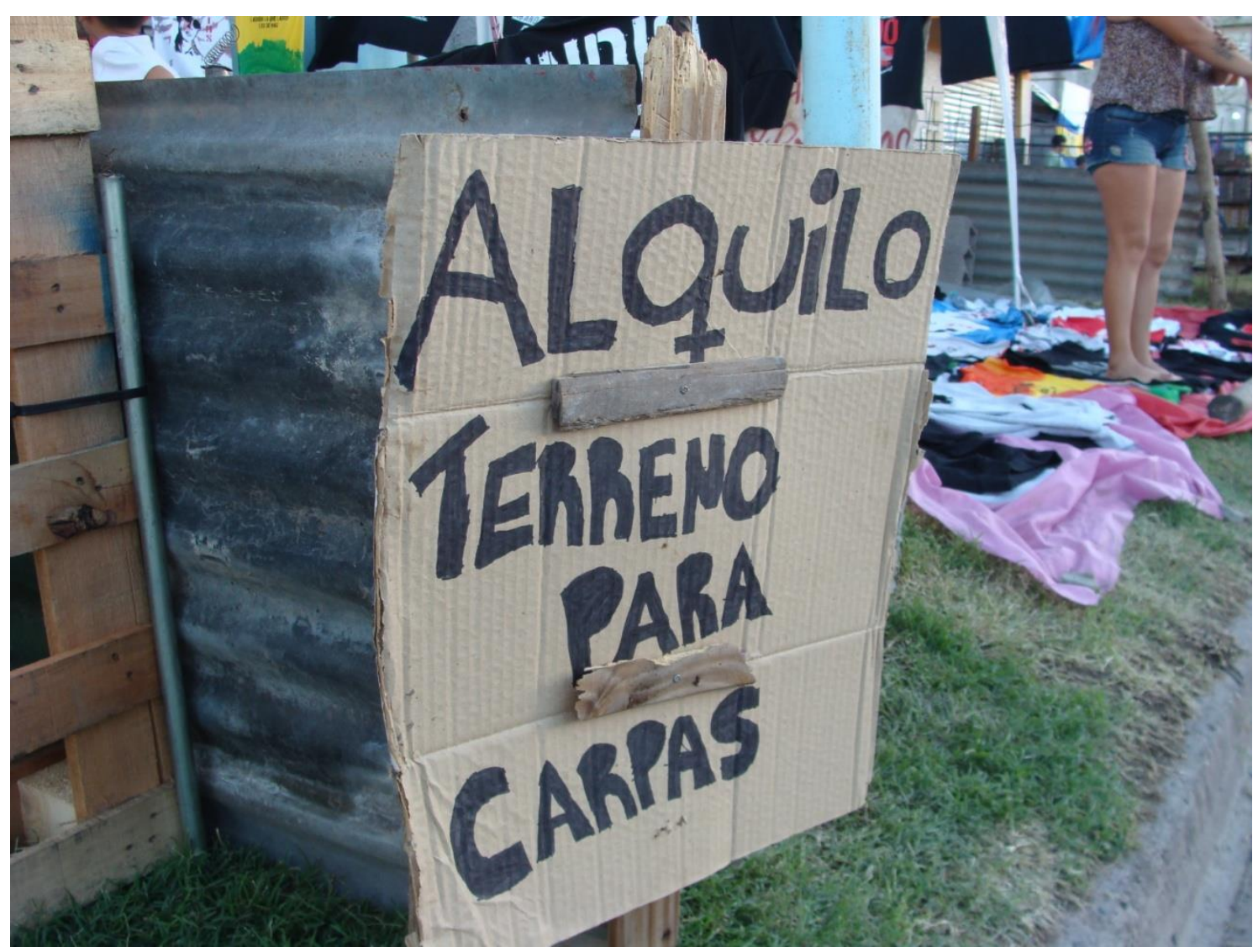

Foto: Silvia Boggi, 09 de marzo 2017.

Otros ciudadanos locales - denunciados y 'escrachados' a través de las redes sociales - estafaron a quienes de buena fe y a distancia alquilaron inmuebles que no existían...

Mientras se va tejiendo el entramado de significaciones y prácticas, en los imaginarios sociales hegemónicos locales referenciados en los y las asistentes al recital se redobla la apuesta acentuando y potenciando la negatividad del colectivo social ricotero: “entraron en la rotisería y arrancaron los pollos del asador", "al pobre chino ${ }^{29}$

\footnotetext{
${ }^{29}$ Se hace referencia a un supermercado no perteneciente a las grandes cadenas internacionales como WalMart o Carrefour, sino a los comercios de migrantes de origen chino instalados en sectores barriales
} 
de la Pringles le robaron todo, el chino no entendía qué pasaba...si apenas habla castellano... se paró a mirar en la puerta y entraron en banda y le llevaron todo. Por eso está cerrado ahora...lloraba el chino", "vienen unas minas descerebradas con nenes chiquitos al recital, qué locura", "recital de drogones, si tirás una pala ahí rajan todos", "A Pedro le pidieron plata en el semáforo y lo amenazaron: si no me das, les vamos a romper la ciudad."

Al calor de los imaginarios agoreros, un pibe olavarriense convida -por las redes sociales- a que el rumor-amenaza se concrete: "espero que destruyan mi ciudad", escribe. Un exceso de literalidad y tal vez una escasa visión metafórica provoca una catarata de posteos admonitorios de ciudadanxs autoadscriptos a la categoría de 'buena gente', que culminan con la descalificación del joven anfitrión: “o hay mucha ironía en el mensaje del muchacho o es un tremendo pelotudo el pibe”. Otro responde, concluyente: "no hay ironía, es un pelotudo". 30

En Facebook algunas iglesias evangélicas locales llaman a cadena de oración ante la realización del recital, la venta de alcohol y drogas "liberadas":

Oro a Dios por olavarria..laverdad..me da pena todo.esto..que la gente tenga miedo que le roben.que el trabajador no pueda abrir su negocio...es muy triste. Y sé que no estoy equivocada. Lamentablemente la idolatría provoca muchas cosas... y el diablo aprovecha de las suyas. oramos a Dios por Olavarría.la iglesia de Jesucristo." 31

En esa misma red social alguien pide "Bin Laden, por favor tirá una bomba en la Avellaneda",32 y en el hospital municipal liberan camas (enviando a sus casas a personas que están internadas, inclusive recién intervenidas quirúrgicamente) porque - según teoriza un médico local- "las mujeres ricoteras tienen el ritual de ir a parir al recital".

De todas las formas posibles, los imaginarios sociales de sentido común dominantes reeditan la idea - casi transformada en axioma- de que Olavarría está siendo invadida por hordas incivilizadas y peligrosas. Es revelador un audio de Whatsapp $^{33}$ del viernes 10 de marzo en donde una mujer insta a sus familiares a aprovisionarse ante el cierre de los comercios locales, cuidarse y advertir a conocidos y parientes, estar alertas ante la inminente llegada de una cantidad descomunal de personas: "todo ese

de la ciudad. En los imaginarios de sentido común se los suele nominar como "los chinos" y concurrir a comprar allí es "ir a los chinos" o "ir al chino".

${ }^{30}$ En Facebook [comentario], HL, GDF, OAG, (comunicación personal), 8 de marzo de 2017.

${ }^{31}$ En Facebook [estado] de MS (comunicación personal), 8 de marzo de 2017). Mantuvimos la grafía.

${ }^{32}$ En Facebook [comentario] de FC (comunicación personal), 6 de marzo de 2017).

33 Audio disponible en: https://ar.ivoox.com/es/audio-sobre-llegada-simpatizantes-ricoterxs-a-olavarriaaudios-mp3_rf_21425997_1.html 
vandalismo" (1200 colectivos y 300.000 personas de Buenos Aires en tren en una sola noche), "se está vendiendo muchísima droga (1500 kilos por día)", "si te llegan a pedir algo no te resistas ni en pedo porque andan todos drogados, en los semáforos" y "no salgan de noche"...

Y frente a la reproducción en Facebook del contenido de ese mensaje de Whatsapp algunos vecinxs olavarrienses replican con la imagen - extraída de la web - de un tren supuestamente hindú repleto de personas ${ }^{34}$, con la leyenda: “Ahi vienen los 300.000 Mariana! Vamos las bandas!!!! ${ }^{35}$

En la página de Facebook de Perros Perdidos de Olavarría, alguien publica: “Atención la gente con perros pequeños de raza!!!!!! Hoy intentaron robar el caniche de una amiga a través de la reja del jardín 3 personas en un auto.....no dejen salir a los perros solos porque si se lo llevan de la ciudad no los ven más". ${ }^{36}$

La ciudad va cambiando hora a hora y día a día, la avenida Avellaneda visitada realizando trabajo de campo parece siempre otra, bajo una luz cada vez más intensa, tanto como la alegría exultante y convocante dando vueltas en el aire.

\footnotetext{
${ }^{34} \mathrm{La}$ imagen con que se replicaba el comentario, disponible en: http://www.siguemirastro.com/wpcontent/uploads/2012/12/TrenIndia-001-300x202.jpg

${ }^{35}$ En Facebook de JO (comunicación personal, 10 de marzo de 2017). "Las bandas refiere en este caso a los y las seguidorxs del grupo musical”.

36 Recuperado de https://www.facebook.com/search/top/?q=perros\%20perdidos\%20olavarria del 10-32017.
} 


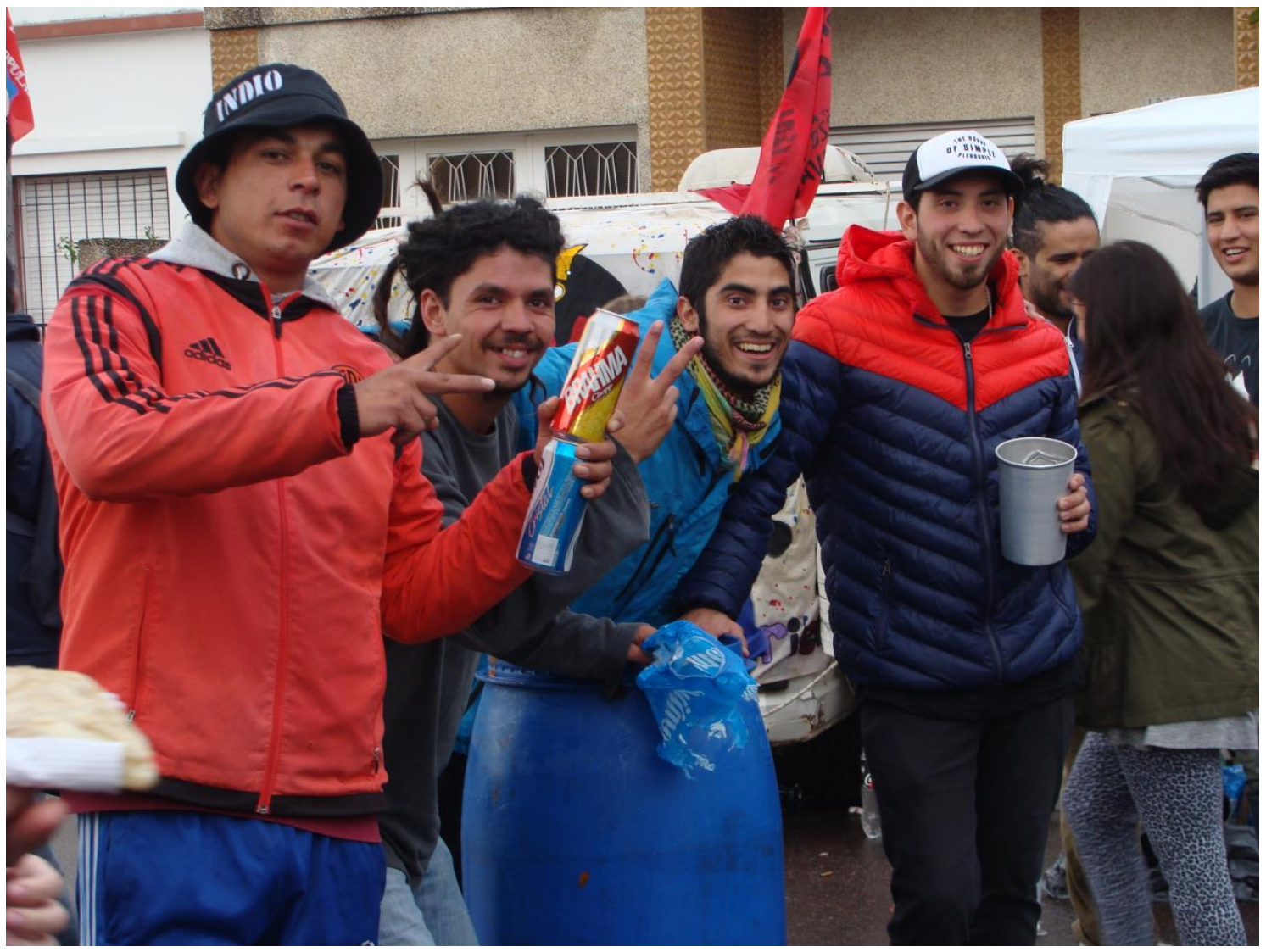

Foto: Silvia Boggi, 11 de marzo de 2017, Olavarría.

Lo único inmodificable es la permanente música de los Redondos, las ruedas de canto generalizado y baile en la vereda, en la calle y en los techos de las casas, los saludos y abrazos, el mareo de la cerveza, del vino y del fernet con Coca, el perfume dulce del cannabis, el humo de los asados, la socialidad compartida y abierta de los consumos, un tiempo demorado y ritual, la significación de "es un sentimiento" vuelta tangible. Todos los géneros, todas las edades, gente de los barrios, gentes del centro de la ciudad y del campo, provenientes de cientos de lugares de Argentina y de otros países, gente con algo de dinero disponible en sus billeteras y gente sin un peso, fiesta embanderada de canciones atravesando clases sociales caminando por la Avellaneda. 


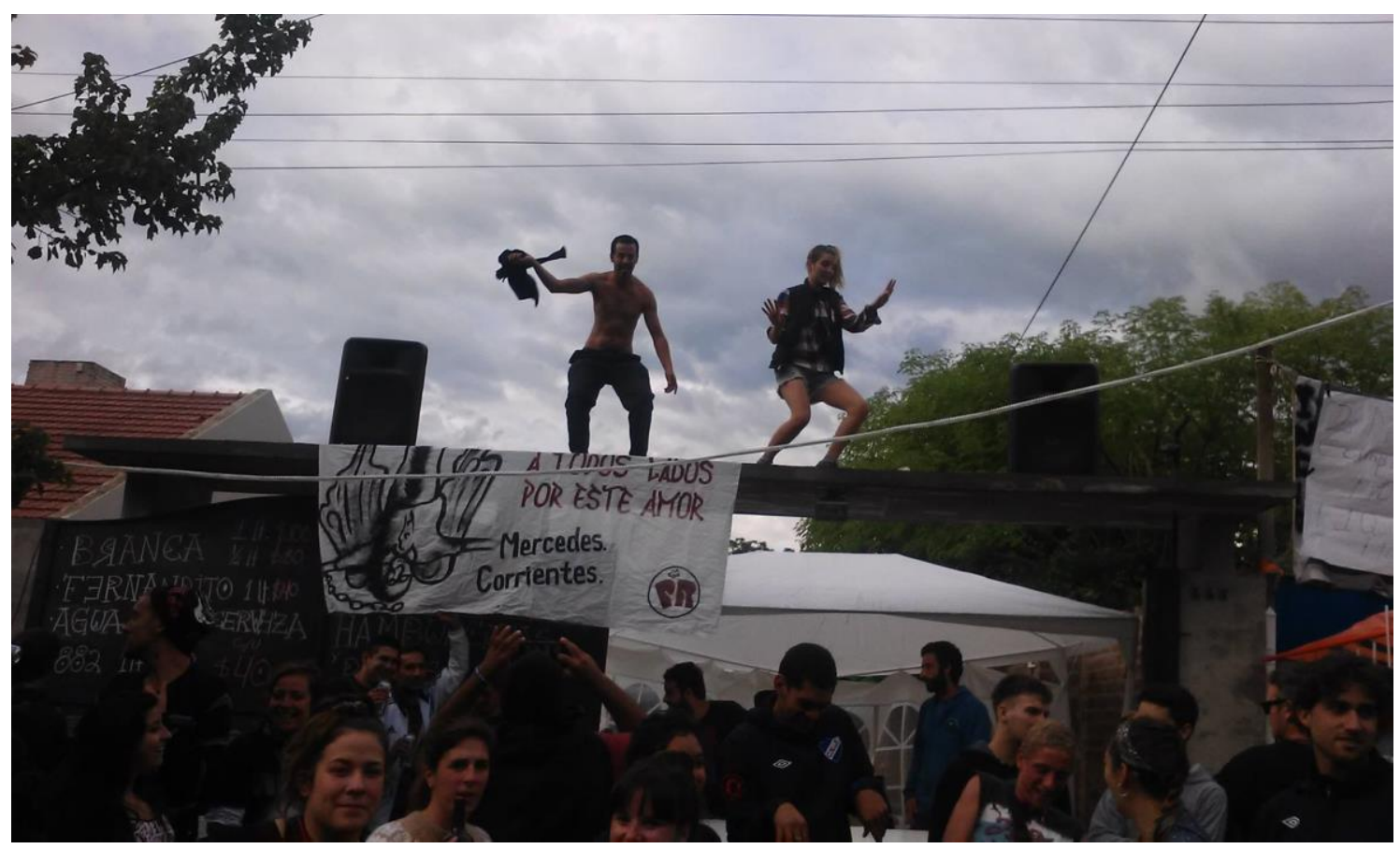

Foto: Marisa Alvarez, 10 de marzo de 2017, Olavarría.

Curiosos novatos van estrenando la sorpresa de estar entre ese universo de alboroto y excesos, mezcla de lenguajes, olores, vibraciones, colores y seguidores empedernidos y ancestrales de la banda. Mundo contradictorio, rústico y áspero, deshilachado y sólido pero dueño de un vuelo sutil, delicado, desgarrado y poético, que se ofrece tal vez como una utopía o un sueño de libertades. Esas que los recién iniciados -transitando su primer "previa"- descubren que los habita desde siempre pero no lo sabían. Pensada bajtinianamente, la "previa" y el "aguante" parecen objetivar la "vida en sentido fuerte". Contra-dicen en avalancha de sentidos la visión hegemónica del deber ser, que desde esta fiesta se percibe como las formas opacas y deslucidas de la gente "amarga, ortiva, cheta y careta".

Mundo que el rock como negocio invita pero no alcanza a balbucear ni saborear aún teniéndolo como bocado en el plato de su mesa. Risas y dormir en el suelo, con frío, compartiendo frazada, abrazados y besándose al lado de un repentino y diminuto fogón. En la esquina, alguna pequeña gresca desarticulada pronta y eficazmente entre los más cercanos... 
Corte de luz, tormenta, lluvia y viento: se vuelan las risas, los toldos, los gorros y el griterío y ¿qué importa? Fiesta pantagruélica y dionisíaca que promete, vociferando y gesticulando en la oscuridad cruzada por las chispas de los fogones que "andate a tocar a la luna, la luna la vamo'a copar"37.

Las veredas y los frentes de las casas se desdibujan a medida que los puestos y kioskos de comidas y bebidas, venta de remeras, artesanías, bijouterie, souvenirs alusivos, sombreros, banderas, van aumentando. Carpas y más carpas, toldos, albergues de nylon en todo lugar en donde quepan: plazas, veredas, parques, clubes, riberas y barrancas del arroyo Tapalqué ${ }^{38}$, campos cercanos, quintas; incontable cantidad de autos, camiones, camionetas, casillas rodantes, ómnibus, por donde se mire. Interminables y lentas caravanas por rutas, caminos y calles, desembocando en las anchas avenidas olavarrienses, con la música ricotera como telón de fondo. Las banderas colgadas en cualquier soporte posible revelan no sólo la adscripción a la banda, sino también a la localidad, provincia o país de origen, el club de fútbol y hasta a veces el barrio - generalmente de sectores populares - de quienes las ha portado hasta aquí: Berisso, La Plata, Monte Chingolo, Salta, Villa María, La Matanza, Córdoba, Mataderos, San Fernando, San Luis, Baradero, Rosario, Mendoza, Rawson, Jujuy, Mercedes, Montevideo-Uruguay... Banderas argentinas, uruguayas, bolivianas, paraguayas mezcladas con las de algunas murgas y comparsas, como Los Barriletes Cósmicos de Tortuguitas. Lo político partidario afirma su presencia: el cartel de 5 metros que forma el frente de un puesto de comidas afirma - sobre fondo de bandera argentina: "Tranqui. Vamos a volver", también coreado a viva voz y agite de brazos junto al "andatemacri laputaqueteparió". Pósters con la imagen de Milagro Sala y la leyenda "Si esta cárcel sigue así todx presx es políticx" y otros con las imágenes del actual Presidente de la Nación y la Gobernadora de la Provincia de Buenos Aires que dicen "Pagan con promesas lxs nenxs de oro" aparecen pegados contra el vallado que rodea al predio donde se realizará el recital. ${ }^{39}$

\footnotetext{
${ }^{37}$ Referencia a una de las canciones de creación colectiva coreada por seguidorxs de la banda durante las llamadas “previas" https://www.youtube.com/watch?v=nOMsDEz01o4

${ }^{38}$ Arroyo que atraviesa a la ciudad de Olavarría, de sur a norte.

${ }^{39}$ Los textos son fragmentos de canciones de la banda Patricio Rey y los Redonditos de Ricota; Todo preso es político y Nuotatori Profesionisti. Los posters llevan el logo de la agrupación política JP Evita.
} 


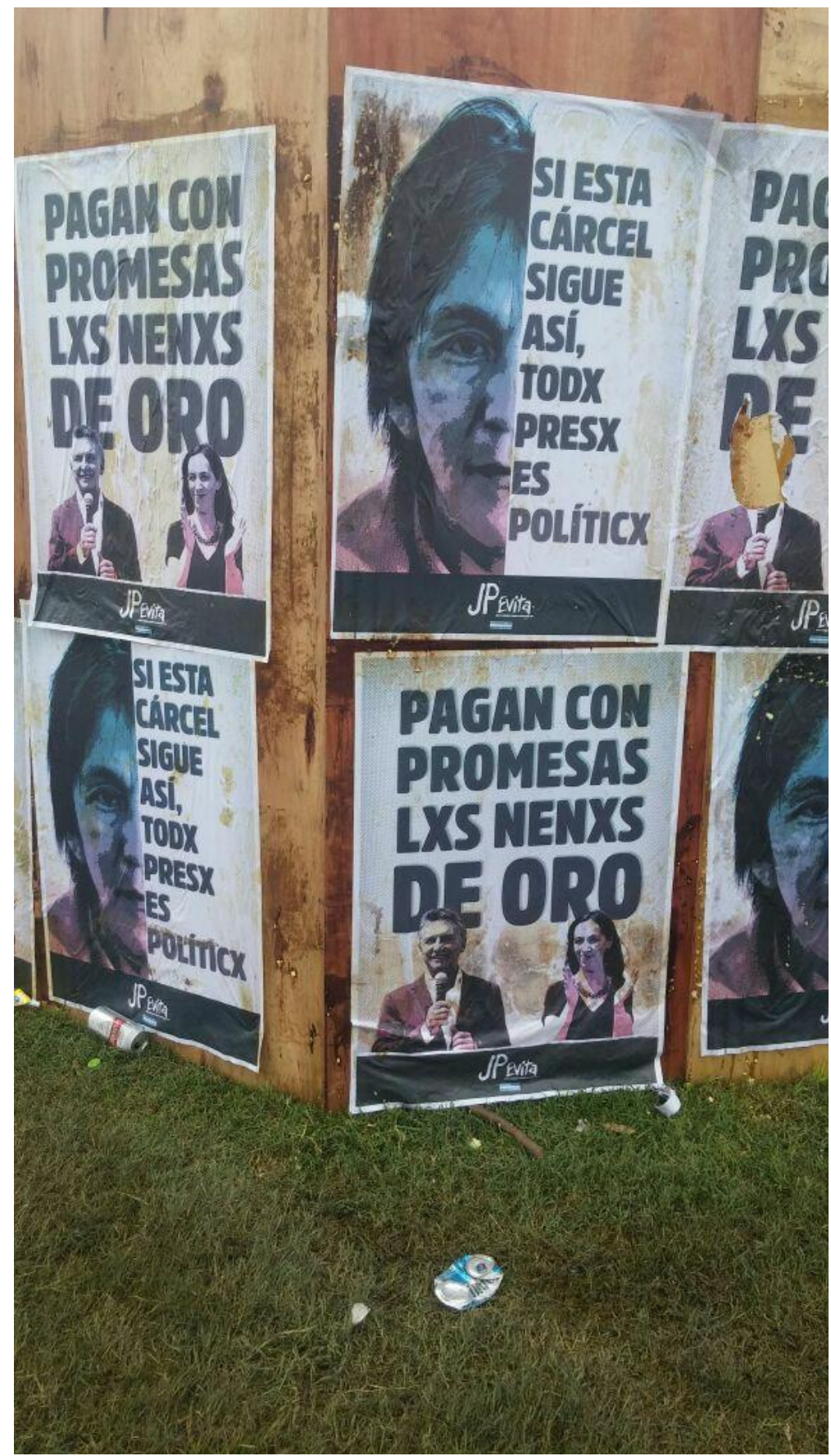

Foto: Dante Lartirigoyen, 9 de marzo de 2017.

La "previa" se derrama ya no solamente en los sitios cercanos al predio de La Colmena, sino en la ciudad entera. La ciudad como un todo está "de previa". No es un tropo ni una evaluación exagerada. "Olavarría explota. En mi vida vi tanta cantidad de gente junta." ${ }^{, 40} 300.000$ ? 500.000 personas esta vez? Cómo saberlo?

\footnotetext{
${ }^{40}$ En Facebook [Estado], SB, 11 de marzo de 2017.
} 


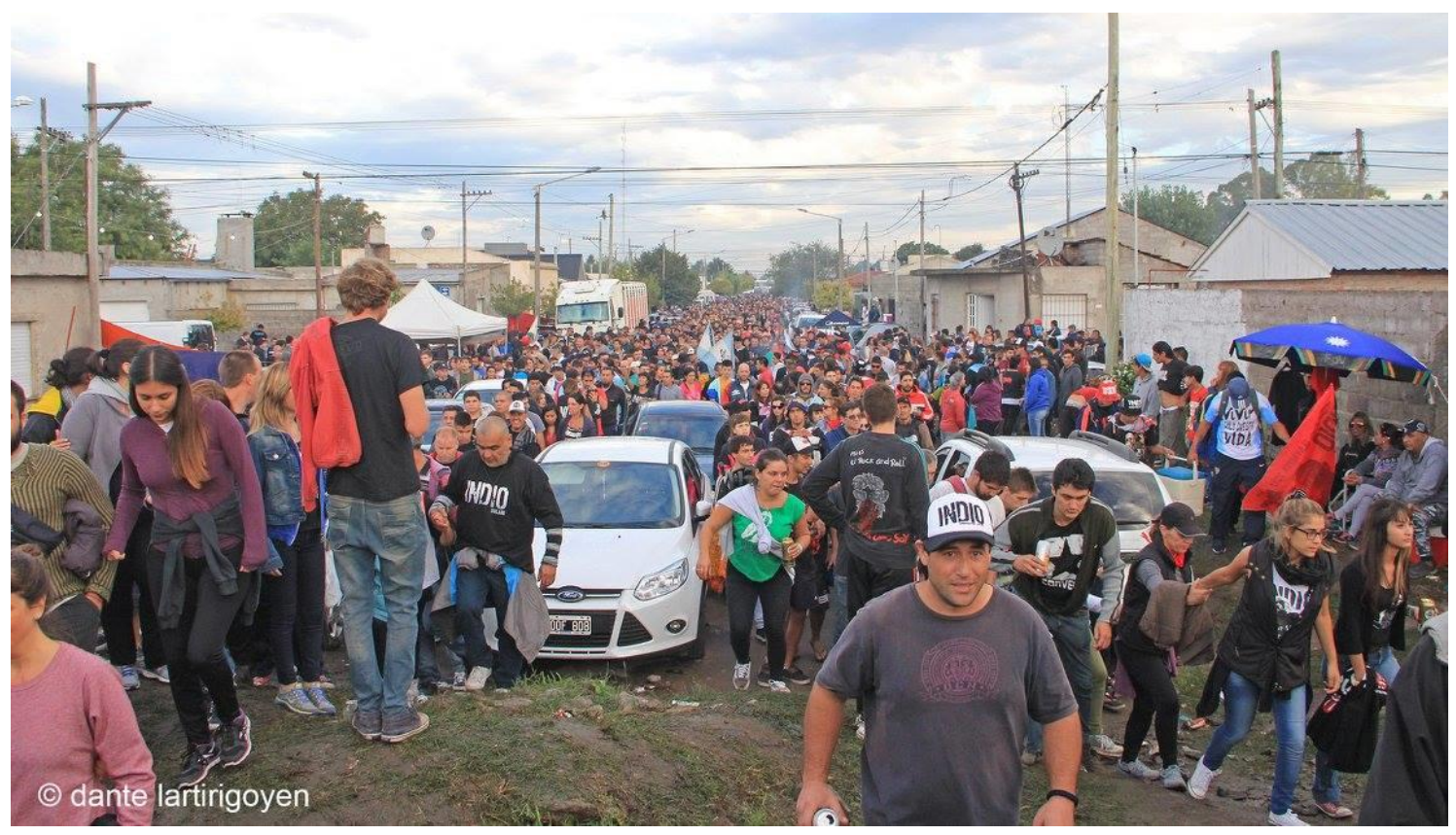

Foto: Dante Lartirigoyen, 11 de marzo de 2017.

La ciudad se va volviendo otra, alteradas sus marcas distintivas. Los barrios por donde se circula todos los días resultan desconocidos, se siente y se huele un espacio recreado a medida de quienes - miles y miles- están llegando a fuerza de corear canciones, de bengalas, pogo - ese mágico y cantado choque festivo entre los cuerpos y Jijiji. ${ }^{41}$ Ciudad estriada que se vuelve lisa desde la mirada deleuziana, recorrido de descubrimiento e improvisación... Ciudades superpuestas, palimpsesto con la estratigrafía al aire, bien visible, con el tiempo cotidiano y gris siendo horadado feliz e irreverentemente a punta de fiesta popular.

41 https://www.youtube.com/watch?v=HKLiLzKy7YI,https://www.youtube.com/watch?v=xLblzj0Xqzc, https://www.youtube.com/watch?v=-UnA0jOLu7U 


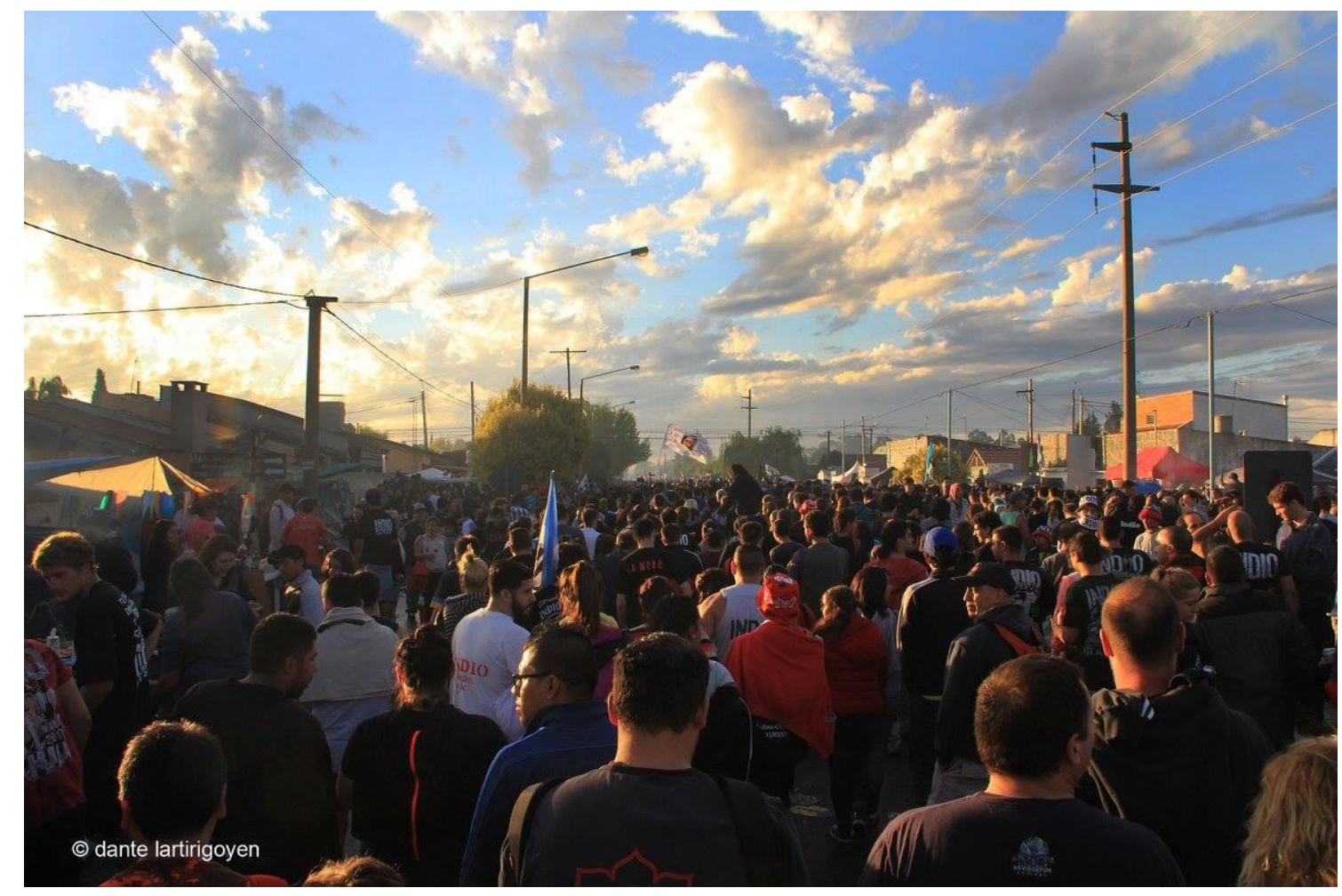

Foto: Dante Lartirigoyen, 11 de marzo de 2017.

$\mathrm{Y}$ en el tironeo discursivo de quienes denuestan las presencias -continuamente más abundantes, alegres, diversas, bulliciosas - de estxs nómades ocasionales, la convivencia - aceptada u obligada- quita en el diálogo, en las experiencias compartidas $\mathrm{y}$ en los pedidos y ofrecimientos, la pátina negativizada, esa quintaesencia del mal objetivada: "Y sí, vos los ves así, todos tatuados, con rastas, tomando cerveza, medio en pedo...pero son buena gente", "estamos teniendo una esperiencia maravillosa con estos pibes", "yo no sé, tanto que dicen, esta gente es espetacular, me pidieron permiso para hacer el asado en el cordón de la vereda, me invitaron a comer y después juntaron toda la basura en una bolsa. Qué fenómeno! la verdá...impecable” ${ }^{„ 42}$. Etnocéntricamente, la Otredad construida empieza a ser pensada como cercanía, como Mismidad, raspando el prejuicio, atravesando fronteras porosas y su inicial exotismo.

Sin embargo, esa cercanía sin barreras del abrazo apretado con desconocidxs no alcanza a todxs: hay quien vende sándwiches, pizzas y empanadas detrás de un enrejado protector armado ad hoc en la ventana de su casa. Y otrxs miran con ojos despectivos y encerrados, a través de los vidrios de ventanas de un primer piso, el despliegue de color, música a todo volumen, cuerpos alegres y la parrilla improvisada sobre cuatro latitas vacías de cerveza en el cordón de su vereda.

\footnotetext{
${ }^{42}$ Respetamos el decir del habla coloquial y los conceptos nativos.
} 
Y faltan todavía largas y ahumadas horas para que -después de un peregrinar por las calles de entrada al recital en un estado de efervescencia y urgencia espiritual y corpórea- y ya de pie ante un imponente escenario flamígero que late, se asista a una breve canción de guerra sioux fundida en orquesta y miles de ansiedades. Y una voz anuncie, "atronando sus nidos" "43: "damas y caballeros, los Fundamentalistas del Aire Acondicionado". 44

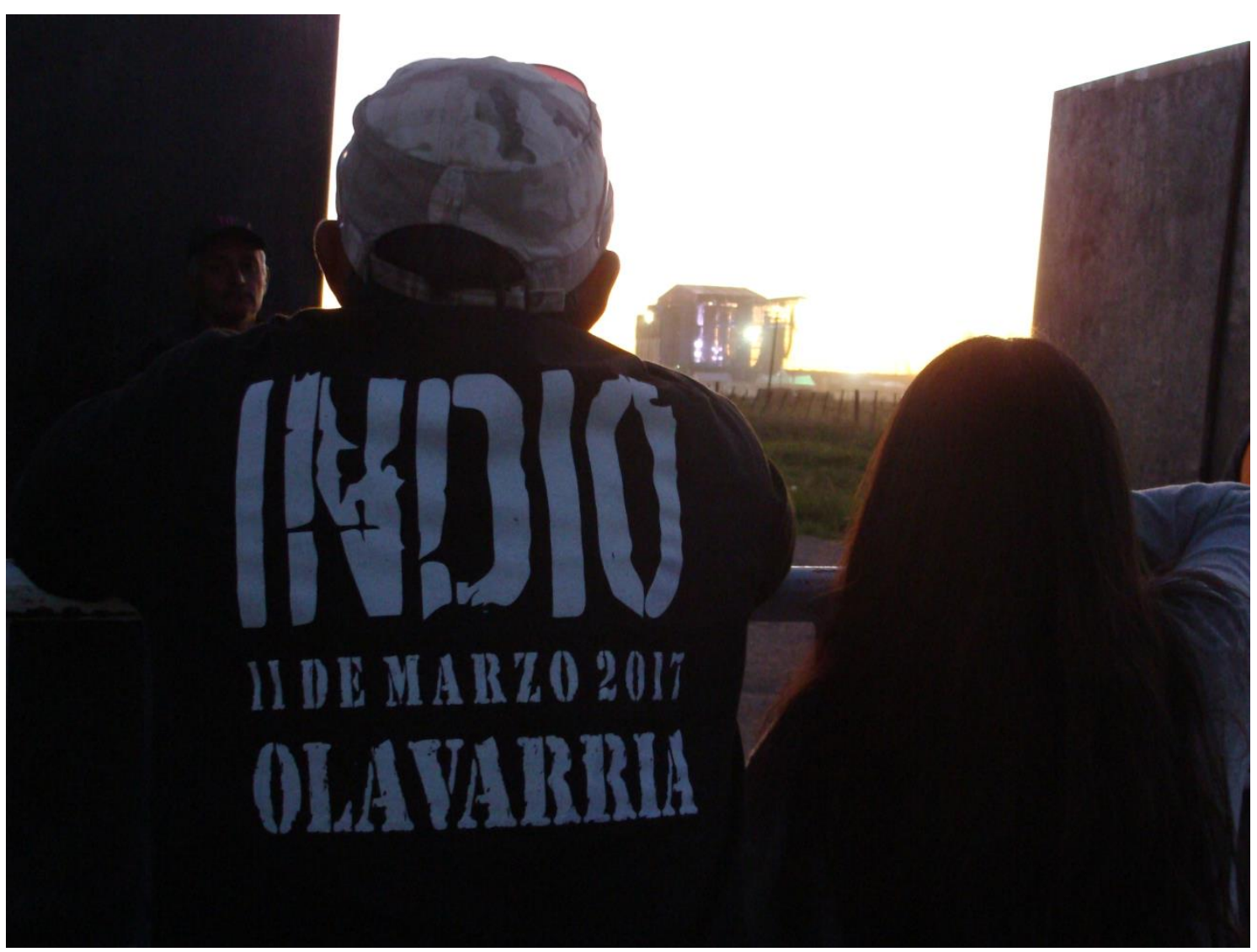

Foto: Silvia Boggi, 10 de marzo de 2017, Olavarría.

\footnotetext{
${ }^{43}$ Referencia al tema Juguetes Perdidos, de la banda Patricio Rey y los Redonditos de Ricota.

${ }^{44}$ Alusión a la intro de cada recital https://www.youtube.com/watch?v=L-_vywGs8-M (Ver en 1:05:05).
} 


\section{"El futuro llegó hace rato" 45 y "20 años no es nada 4 ",}

De las múltiples y complejas aristas que encierra la relación vital y específica entre el mundo del rock y el mundo urbano, nos interesa hacer foco en aquellas que se plantean entre bandas musicales, sus públicos y las ciudades de rango intermedio. En este caso, una banda del rock “chabón" es la punta de lanza que arma una excusa para pensar la operatividad de algunos conceptos que podrían ser marcadores de especificidad de un centro urbano como Olavarría.

Si comparamos nuestro actual registro etnográfico con discursos y prácticas ocurridas en la ciudad hace 20 años quedan revelados elementos de profunda continuidad ideológica en los imaginarios sociales hegemónicos respecto de la construcción de otredades amenazantes referenciándolas en actores sociales que participan de los conciertos de Solari, sus actos de nomadismo ocasional y ocupación transitoria de espacios urbanos.

Asimismo es posible advertir cómo las expresiones que asume esa construcción, atravesando la dimensión histórica de la ciudad de Olavarría, activan la sistemática discusión en torno a su carácter pueblerino o citadino -con su correspondiente carga axiológica- a partir de la realización de eventos culturales como el que reseñamos.

Olavarría tiene en su historial una trayectoria importante en la gestión de festivales y fiestas locales, regionales y de amplitud nacional que implican la llegada de grandes contingentes que comparten el uso del espacio urbano durante algunos días cada año. Baste recordar - dentro de las públicas- las competencias de Turismo Carretera - que hemos analizado (Boggi, 2001) - y otras categorías consideradas 'menores' del automovilismo deportivo, la organización de recitales de rock de mediana envergadura, festivales de doma y folklore, las festividades organizadas por localidades cercanas como Colonia Hinojo y Sierras Bayas. Todas ellas implican el traslado de personas de la zona, de la región y del país, la convivencia durante lapsos temporales con quienes habitan la ciudad, compartiendo el espacio público. Sin embargo ninguna ha generado ni genera una efervescencia negativa en los imaginarios sociales de sentido común dominante tan profundamente ligada al miedo y a la construcción de fronteras morales de alta intensidad. Fronteras que se erigen doblemente hacia "afuera" de la

\footnotetext{
${ }^{45}$ Referencia a la letra de la canción Todo un palo, de Patricio Rey y los Redonditos de Ricota, del álbum Un baión para el ojo idiota, 1987.

${ }^{46}$ Referencia a la letra del tango Volver, compuesto en 1934 por Carlos Gardel y Alfredo Lepera.
} 
ciudad y hacia "adentro", aportando a la fragmentación en los imaginarios locales o reactivándola.

Cuando en 1997 el Intendente Helios Eseverri decretó la prohibición de la realización en Olavarría de dos recitales de la banda Patricio Rey y los Redonditos de Ricota $^{47}$ - gestionados de forma privada por el Club Estudiantes local y a realizarse en sus instalaciones- lo hizo respondiendo a la demanda preocupada de un amplio arco social que incluía a sectores de relevancia y de peso político y económico en la ciudad que compartían una visión prejuiciada acerca de los seguidores de la banda. Esos imaginarios estaban presentes en la prensa hegemónica nacional que presentaba noticias de los recitales de la banda en asociación directa con hechos de violencia y con un pronunciado protagonismo de las fuerzas policiales desplegando un intenso accionar represivo: detenciones masivas, razzias, gases lacrimógenos, golpes, torturas. ${ }^{48}$ En el sentido común extramediático dominante decantó en la construcción de un paradigma ${ }^{49}$ que negativizaba y demonizaba a la banda musical y más que nada a sus seguidores, mayoritariamente jóvenes y pertenecientes a las clases menos favorecidas de la sociedad neoliberal de los ' 90 .

Así, el discurso alarmista y discriminatorio que sostenían las conciencias de aquella "buena sociedad" local incluía desde el temor a que "violen mujeres en cualquier esquina" (refiriéndose a ciudadanas olavarrienses), "que roben a la gente y en los negocios" y hasta "que rompan todo (la ciudad)". En el diario local El Popular del 17 de agosto de 1997, la Unión Vecinal expresaba su apoyo a la decisión del Intendente:

sabiendo que existen riesgos serios para alterar la normalidad de la ciudad, que los seguidores de este grupo son fanáticos que, cegados por los efectos del alcohol y la droga son capaces de cualquier vandalismo" (...) "No vemos por qué invocar la libertad absoluta como punto de partida para defender la realización del recital poniendo en riesgo hasta la integridad física de nuestros hijos que transitan tranquilamente por nuestra ciudad, por el solo hecho de sacarle un rédito político a la cuestión. Si medidas de estas características sirven para mantener la calma de nuestra ciudad, bienvenidas sean.

\footnotetext{
${ }^{47}$ Cabe señalar que meses antes, el intendente de la ciudad santafecina de Arroyo Seco, Pedro Spina, había procedido a prohibir la realización en la localidad de recitales de la banda Patricio Rey y los Redonditos de Ricota previstos para los días 6, 7 y 8 de diciembre de 1996.

${ }^{48}$ Es emblemático el caso de Walter Bulacio, joven de 17 años cuya muerte se produjo como consecuencia de esos procedimientos implementados hacia los seguidores de la banda. El 26 de abril de 1991 falleció luego de seis días de agonía tras la golpiza que recibió en la comisaría 35 de la Capital Federal. Ese hecho fue el que provocó las primeras movilizaciones antirrepresivas en democracia. Masivas convocatorias comenzaron a exigir castigo a los culpables y responsables de los asesinatos que seguía ocasionando el aparato represivo del Estado aún en tiempos democráticos.

${ }^{49}$ En el sentido de las relaciones asociativas de Saussure (Castellani, 1997).
} 
El entonces senador provincial Ernesto Cladera sumaba su voz ${ }^{50}$ a favor de la prohibición:

El grupo eligió Olavarría no por el público local sino porque no pueden realizarlo ni en Capital Federal ni en el Conurbano bonaerense porque no pueden garantizar la seguridad de los asistentes y vecinos (...) Nos ha costado mucho construir la Olavarría que tenemos, un esfuerzo muy grande sentar las bases del crecimiento y de hombres íntegros para dirigirla.

Las expresiones discursivas sostenidas desde esos imaginarios sociales son homólogas respecto de aquellas que aparecen en los informes que la Dirección de Inteligencia de la Policía de la Provincia de Buenos Aires elaboró con motivo de la realización en agosto de 1997 de los recitales de la banda liderada por el "Indio" Solari en la ciudad. Estos - dados a conocer en 2015 por la Comisión Provincial de la Memoria - revelan no sólo los dispositivos de vigilancia y las acciones de inteligencia realizadas en Olavarría sino las representaciones existentes en los imaginarios sociales locales sobre la banda y sus seguidores, que sirvieron para fundamentar y justificar la prohibición de los recitales decretadas por el entonces Intendente Helios Eseverri y la Cámara en lo Civil y Comercial de Azul. ${ }^{51}$

En el informe ${ }^{52}$, la banda es calificada como "grupo subte o underground", originada en la década del '70 en la ciudad de La Plata y sus integrantes

\begin{abstract}
desde siempre tuvieron una actitud combatiba (sic) en cuanto a todo lo que podía llegar a identificarlos con "El SISTEMA", ya sea en lo político, comercial o a la televisión a la cual se han negado sistemáticamente a aparecer (...) Estas actitudes se expresan en los textos de las letras de las canciones escritas por el "Indio SOLARI" que si bien no tienen una estructura tradicional, el mensaje está pero se necesita conocer el código para descifrarlo. Para una persona que las escucha por primera vez, las letras NO DICEN NADA y diría que carecen de sentido". Sus seguidores son identificados como "LOS CHICOS DE LAS BANDAS", advirtiendo que "es difícil distinguir" a quienes las integran: "pueden ser melenudos o pelados, rubios o negros, de Capital, San Isidro, Mataderos o La Plata...pero cada uno de ellos cumple una serie de formalidades espirituales: a) creer que se puede vivir de manera distinta a la que vende la televisión, b) que esta vida es la única vida y que en el shopping oficial sólo se compra basura, c) que una "corbata" no es una prenda de vestir sino una soga que ahorca a su dueño, d) que el "movicón" es un remedio para la soledad, e) que el mejor policía es el POLICÍA MUERTO.” Según el informe de la fuerza policial se trata de "jóvenes que son la BARRA BRAVA que le da una verdadera consistencia a los Redonditos de Ricota a quienes siguen como si fuera un CLUB
\end{abstract}

\footnotetext{
${ }^{50}$ Diario El Popular, 17 de agosto de 1997. El remarcado en itálica es nuestro.

51 Otros documentos dados a conocer por la misma Comisión revelan el espionaje y vigilancia que realizó la actualmente disuelta Dirección de Inteligencia bonaerense en los recitales que Patricio Rey ofreció en los 90, entre ellos los archivos vinculados con los shows de Lanús, Huracán, Tandil y Mar del Plata.

52 En: https://www.diarioregistrado.com/no-se/exclusivo--los-archivos-sobre-la-persecucion-a-losredondos-en-los-90_a5660c7bda424ffcb0aa20301. Mantuvimos la grafía del documento.
} 
DE FUTBOL" y como dato adicional afirman que la banda cuenta con "admiradores que no son tan jóvenes y los siguen desde sus comienzos" y que la barra brava del Club Chacarita Juniors forma parte de los seguidores.

\section{Señalan que}

en abril de 1991 se produce la muerte de un fans (sic) a la salida del Estadio Obras Sanitarias de Capital Federal, también se registran episodios de violencia a la salida de los recitales brindados en el Gran Buenos Aires y gran parte de la PRENSA ESPECIALIZADA se enfrentó a ellos.

Califican a la banda de rock como el fenómeno taquillero que dio la cultura alternativa en la última década. El análisis que expone el documento acerca del contexto de recepción de la banda es revelador de los imaginarios sociales dominantes:

marcada preocupación de las familias vecinas a las instalaciones del Club Estudiantes (...) que se extiende a varias cuadras del lugar" (...) quienes con mucho temor se mantendrán en sus domicilios sin abandonar los mismos y extremando las precauciones en lo que a sus seguridades respecta", preocupación compartida por el sector comercial y por los remiseros, "que temen por aquellas personas que vendrán desde Capital y/o Gran Buenos Aires cuyos antecedentes no son del todo favorables...

Si bien en el caso olavarriense hubo voces institucionales que repudiaron la determinación oficial, ${ }^{53}$ no lograron desatar el nudo de las lexías hegemónicas, del camino autoritario que habilitó la prohibición de un hecho cultural y de la afectación de derechos y libertades:

Al intendente [Eseverri] se le ha ocurrido introducirnos a los olavarrienses en un túnel del tiempo que nos retrotrae a las épocas más oscuras de nuestro país (...) no hace falta más que leer el decreto de prohibición de un espectáculo musical que nos ubica más cercanos a la época de la Inquisición que al próximo milenio. ${ }^{54}$

El ex intendente local Carlos V. Portarrieu ${ }^{55}$ en ocasión de la celebración pública de sus 80 años había dado la noticia de sus gestiones para la realización de los recitales de la banda en las instalaciones del Club Estudiantes de Olavarría que por entonces

\footnotetext{
${ }^{53}$ Entre otros, el Partido Intransigente local y la Mesa local del FREPASO, periodistas olavarrienses, el centro de estudiantes de la Facultad de Ciencias Sociales de la Unicen mediante una nota declaró "persona no grata" al Intendente Helios Eseverri.

${ }^{54}$ Nota del diario El Popular del 17 de agosto de 1997, el texto corresponde al pronunciamiento del Partido Intransigente local.

${ }^{55}$ Ex intendente de la ciudad en varios períodos, inclusive durante la dictadura.
} 
presidía. El anuncio era rememorado así en una nota del diario El Popular del 22 de julio de 1997:

Siempre pensando en grande, hasta hizo una referencia a los Redonditos de Ricota que pronto llegarán y se establecerán en el club que él preside. Y dijo que nosotros también tenemos que prepararnos para algo que seguramente no encaja en tradiciones pueblerinas. Pero será algo notable, que nos muestra por otra parte que no nos va a alcanzar nuestra infraestructura.

¿Qué es lo que se erige como conjunto de valores en este trazado de fronteras morales que atraviesan la distinción entre ciudad y pueblo? Las fronteras morales, explican Daniel Buraschi y María José Aguilar (2016: 127):

son necesarias para justificar nuestra visión del mundo, nuestro horizonte de significado que da sentido a nuestra identidad, nuestra pretensión de humanidad, universalidad y superioridad moral, siendo de relevancia señalar que son mecanismos que legitiman prácticas institucionales y decisiones políticas.

En el caso que nos ocupa los imaginarios sociales dominantes locales fueron pródigos en discursos edificados sobre la idea de que la llegada de seguidores de la banda implicaría la amenaza de la pérdida de imaginados atributos de las ciudades intermedias o del tipo ideal pueblerino folk deshistorizado y esencializado ${ }^{56}$ : la calma y la tranquilidad, la seguridad, la integridad física, el transitar el espacio urbano sin inconvenientes, una "normalidad" sin alteraciones, el cuidado de los bienes públicos y también privados.

Ese reservorio significacional estuvo en disponibilidad veinte años después como elemento residual (Williams, 1988:130) - para catalizar la interpretación de la realidad local y contextual del presente. Las fronteras morales construidas desde el sentido común dominante amurallan ese mundo igualmente idealizado y acrítico encerrando a un "nosotros" erigido como modelo ejemplar frente a la presencia inevitable, estereotipada, prejuiciada y temida de "esos otros" cuya llegada es interpretada como aluvión, como invasión temida. O prohibiendo la realización del acontecimiento que convoca a esa "gente indominable", "las hordas", "todo ese vandalismo", "los fanáticos cegados por el alcohol y las drogas", "el malón de gente", "los que vienen del Bs.As. y el conurbano con antecedentes no del todo favorables", "los que van a violar mujeres en las esquinas", "los que sitian la ciudad". Y esas fronteras construidas con el material sígnico de los imaginarios sociales dominantes se

\footnotetext{
${ }^{56}$ Cfr. Boggi, Silvia y Nora Galván (2016), Gravano (2005).
} 
encabalgan sobre la paradoja de erigirse, reactualizadas, para separar y proteger una especie de indefenso poblado de lo que se le aparece - construido con su propia argamasa - como la condensación ese infierno tan temido: lo salvaje-urbanometropolitano...

Por eso las voces que ponen en cuestión los miedos de la "buena vecindad", la escalada prejuiciosa, la violencia simbólica de la desconfianza exacerbada y casi de una desproporción y desmesura rabelesiana, sacuden el territorio de lo folk y reclaman no ser incluidas en un pasado medieval, inquisitorial y autoritario, ni en un lugar donde se experimenta el "atraso", ni desean sentirse "Preso en mi ciudad" ironía desde el humor gráfico del dibujante local Guile: "En el siglo XXI Olavarría será suspendida por llegar tarde"

Las expresiones de quienes gestionaron y gestionan a Olavarría hacen ostensible esa tensión de cara a la realización del recital de la banda liderada por el Indio Solari: el ex intendente Carlos Portarrieu invitando en 1997 a "prepararnos para algo que seguramente no encaja en tradiciones pueblerinas" y el actual intendente Ezequiel Galli, en 2017, sosteniendo en los días previos al recital para aventar los temores de cierta parte de la ciudadanía local: "somos una ciudad grande y estamos para cosas grandes".

En un posteo de Facebook sugería una vecina:

a Olavarría le hacen falta más recitales. Mas recitales solamente? con el atraso mental de mucha gente creo que hace falta mucho mas de todo acá: cultura, educación y calle, hace falta calle, acá. Hace falta menos ignorancia acá, la cultura del que no le tiene miedo al otro ser humano.

Otro respondía en la misma red social: "Leo cada publicación con respecto al recital que dan pena!! Por qué no dejan vivir la fiesta en paz. Una pena que Olavarría siga siendo un pueblo y no una ciudad. Se lee mucho trogloditas". Y una olavarriense, ironizando, sintetiza de manera precisa la tensión dilemática: “Alambramos la ciudad y listo $!^{59}$

\footnotetext{
57 Título de una nota del periodista Guillermo Del Zotto, Diario El Popular de Olavarría del 17 de agosto de 1997.

${ }^{58}$ Diario El Popular de Olavarría, 17 de agosto de 1997.

59 En Facebook [Estado] Comunicación personal, BM, 8 de marzo de 2017. Mantuvimos la grafía original. El remarcado en itálica es nuestro.
} 
Como en una balanza cuyas pesas son colocadas alternativa pero simultáneamente en uno u otro plato, Olavarría oscila frente a un espejo bifronte que le propone su mítica imagen pueblerina "donde-nunca-pasa-nada" y su antítesis: las promesas de ciudad pujante donde anida el mito del progreso, con vocación de metrópoli acentuada en cada mito que la inviste como "Capital de".

Pero en ese vaivén también hace su nido - gestionando paradojas - el espesor histórico de contradicciones y conflictos constitutivos de lo urbano, la ciudad como arena de lucha - en el sentido de Valentín Voloshinov - que se expresa entre otras formas, mediante la construcción y reproducción de fronteras morales con la capacidad de generar dispositivos de inclusión/exclusión a grupos e individuos respecto de ese territorio vivido, en este caso, la ciudad de Olavarría.

Lo hace también mediante un registro de lo popular que al jaquear estos valores hegemónicos los contradice y 'acorrala': la propiedad privada, la mesura y la moderación en los consumos, el "orden" y la disciplina corporal; el temor al feliz descontrol, el atreverse a riesgos - hasta fatales - de los excesos, la promiscuidad adjudicada al latido de la vida nómade temporaria y ocasional. Este desafío de las lógicas dominantes - del que sólo aproximamos aquí unas hebras del ovillo - al escenificarse en los espacios de las ciudades intermedias parece instaurar dominios provisorios que muestran que otros órdenes vitales son posibles. Des-sujetados y adscriptos a lo autonómico - en un juego dialéctico con los nudos hegemónicosritualmente compartidos, entendidos desde lo popular en sentido gramsciano, saltan por sobre las distinciones dominantes, las desbaratan y propician cronotopos donde la ciudad - Olavarría- es para todxs.

\section{Referencias}

BAJTIN, Mijail. La cultura popular en la Edad Media y en el Renacimiento, Madrid, Alianza, 1980.

BOGGI, Silvia. Un lugar en el podio. Olavarría, Capital del TC. La construcción de una identidad urbana en tiempos de crisis. Tesis para la obtención de la Licenciatura en Antropología Social, Facso, Unicen, 2001. Inéd.

BOGGI, Silvia. Identidades urbanas locales en Facebook. Reflexiones acerca del trabajo de campo etnográfico en el ciberespacio. En: VILLAFAÑE, A y ADAD, L. Antropologia y crisis global: desafios para una interpretación desde el sur. Depto. de Antropología y Nures, Facso, Unicen. 2011.

BOGGI, Silvia y Nora GALVAN. Ciudad media, ciudad intermedia ¿ni chicha ni limonada? En: GRAVANO, A., SILVA A. y BOGGI, S. Ciudades vividas. Sistemas e imaginarios de ciudades medias bonaerenses, Bs.As., Café de las ciudades, 2016. 
BOIMVASER, Jorge. A brillar, mi amor. Mitología no autorizada de Patricio Rey y los Redonditos de Ricota, Bs.As. Penguin Random House Grupo Editoral Argentina, 2016. BURASCHI, Daniel y María José AGUILAR. Indiferencia, fronteras morales y estrategias de resistencia. En: Documentación Social, Nro. 180, Ed. Caritas Española, 2016, pp.127-147.

DELEUZE, Gilles y Felix GUATTARI. Mil mesetas. Capitalismo y esquizofrenia. Valencia, España, Ed. Pretextos, 2002.

GRAMSCI, Antonio. Observaciones sobre el folklore. En su: Cultura y Literatura, Barcelona, Península, 1971.

GRAVANO Ariel (comp.), Imaginarios sociales de la ciudad media: emblemas, fragmentaciones y otredades urbanas. Estudios de antropología urbana, Tandil, REUN, 2005.

GRAVANO, A., SILVA A. y BOGGI, S. Ciudades vividas. Sistemas e imaginarios de ciudades medias bonaerenses, Buenos Aires, Café de las ciudades, 2016.

SAMPIETRO, Darío. Los Redondos y las noticias. Una mirada hacia el complejo mundo entre la prensa y los fenómenos musicales. Tesis de grado, Depto. de Sociología, Unmdp, 2017. http://humadoc.mdp.edu.ar:8080/bitstream/handle/123456789/535/Dar\%C3\%ADo\%20 Sampietro.pdf? sequence $=1$

SEMAN, Pablo. Vida, apogeo y tormentos del "rock chabón". En: Pensamiento de los confines, Fondo de Cultura Económica, 2005.

SEMAN, P. y VILA, P. "Rock Chabón e identidad juvenil en la Argentina neo-liberal" En: DANIEL FILMUS (Ed), Los noventa. Política, sociedad y cultura en América Latina y Argentina de fin de siglo, (ed.), Buenos Aires, EUDEBA, 1999.

SILVA, Ana. El barrio patrimonial. Imaginarios identitarios urbanos y producción de lo público en una ciudad intermedia de la provincia de Buenos Aires. En: Revista colombiana de antropología, vol 51, nro 1, enero-junio de 2015, ICANH, Colombia.

VOLOSHINOV, Valentín. El marxismo y la filosofía del lenguaje, Madrid, Alianza, 1992.

WILLIAMS, Raymond. Marxismo y literatura, Barcelona, Península, 1988.

Recebido em: 21/09/2017.

Aprovado em: 15/11/2017. 